\title{
Przemoc filosemicka
}

\author{
Elżbieta Janicka, Tomasz Żukowski
}

\section{Inkluzja pośmiertna?}

„W niektórych środowiskach - pisze Paul Zawadzki w Historii antysemityzmu pod redakcją Léona Poliakova - odnosi się nawet wrażenie, że nastąpiła zmiana znaku wartości przypisywanego Żydom; antysemityzm został zastąpiony pewnego rodzaju filosemityzmem. [...] Wszystko wskazuje na to, że po śmierci fizycznej w czasie Szoa, symbolicznej w momencie wygnania w 1968 r. i metaforycznej po upadku komunizmu Żydzi, lub przynajmniej ich prochy, zostaną włączone do panteonu kultury polskiej” [Poliakov (red.) 2010: 247] ${ }^{1}$. Idea pośmiertnej inkluzji wymaga sproblematyzowania. Wiąże się z nią na przykład pytanie, na ile wolno abstrahować od faktu, a także przyczyn i okoliczności śmierci - obiektu inkluzji. Chodzi tu bowiem o inkluzję, którą żywi aplikują martwym. Dodatkowo działania tego dokonuje większość na mniejszości: grupa dotychczas wykluczająca na grupie wykluczanej i ostatecznie wykluczonej.

Interesują nas warunki, na jakich dokonuje się dzisiaj w Polsce owa inkluzja pośmiertna. Pragniemy poddać analizie składające się na nią praktyki. Dostrzeżenie tych praktyk uświadamia, że tam, gdzie w grę wchodzi utrwalona w kulturze i długotrwała przemoc wobec mniejszości, przepracowanie i odrzucenie wzorów powielających i utrwalających dyskryminację okazuje się niezwykle trudne. Dawne formy podporządkowania ustępują miejsca nowym - niekiedy na przekór najlepszym intencjom.

Chcemy przyjrzeć się temu procesowi na przykładzie filmu Po-lin. Okruchy pamięci Jolanty Dylewskiej z 2008 r., który traktujemy jako świadectwo inkluzyjnych intencji i praktyk nieodosobnionych w kulturze współczesnej Polski. Film przyjęto entuzjastycznie². Odebrano go jako odtrutkę na antysemityzm i jednocześnie zaproszenie do rozmowy o historii polskich Żydów na zupełnie nowych zasadach. Podkreślano z uznaniem, że Jolanta Dylewska wybrała punkt widzenia krańcowo różny od perspektywy Jana Tomasza Grossa. W opinii recenzentów reżyserka zaproponowała odnowicielski język, „pomijając

1 W cytowanej wypowiedzi P. Zawadzkiego zwraca uwagę bezkrytyczne - i de facto legitymizujące - zastosowanie antysemickiego mitu „żydokomuny”. Por. opracowania analityczne: Zawadzka 2009; Grabski (red.) 2007.

2 Film otrzymał nagrody takie, jak Nagroda Publiczności „Złote Zęby” na Festiwalu Filmu Polskiego w Chicago (2008 r.); trzecia nagroda w kategorii pełnego metrażu na Festiwalu Filmu i Sztuki „Dwa Brzegi” w Kazimierzu Dolnym (2008 r.); Nagroda im. Krzysztofa Kieślowskiego „Ponad Granicami” na Festiwalu Filmów Polskich w Nowym Jorku (2009 r.); główna nagroda „Złoty Feniks” na Międzynarodowym Festiwalu Filmowym „Żydowskie Motywy” w Warszawie (2009 r.); nagroda „Złota Taśma” Koła Piśmiennictwa Filmowego Stowarzyszenia Filmowców Polskich (2009 r.). 
zupełnie kwestie winy, wzajemnych pretensji, antysemityzmu i antypolonizmu" - jak napisał w tygodniku „Polityka” Janusz Wróblewski [Wróblewski 2008]³.

Tadeusz Sobolewski nazwał obraz „filmowym aktem pojednania” [Sobolewski 2009/2010: 14]. „Dylewska zrobiła film o życiu, nie o Zagładzie” - stwierdzał w obszernej recenzji na Łamach „Gazety Wyborczej” [Sobolewski 2008: 13]. Z tekstu wynikało, że życie jest dla Sobolewskiego obszarem, gdzie ujawnia się głęboka prawda polsko-żydowskich stosunków, zapomniana i różna od obrazu wyłaniającego się ze świadectw czasu wojny ${ }^{4}$. Po-lin zaś odsłania ją i pozwala do niej powrócić, stanowiąc terapię dla obu okaleczonych Zagładą grup. „Tamten żydowski świat zostaje przez nas przyswojony dopiero wtedy, kiedy przestał istnieć" - pisał Sobolewski. I dodawał, powołując się na autorytet mający reprezentować stanowisko żydowskie: „Do podobnej konkluzji doszedł Antoni Słonimski w wierszu Elegia miasteczek żydowskich: wierzył, że to, czego nie ma, pozwoli «zbliżyć bratersko i złączyć od nowa/ dwa narody tym samym karmione cierpieniem». Czy tak nie bywa między najbliższymi ludźmi, że zaczynamy kogoś doceniać i kochać, kiedy go zabraknie?" [Dylewska 2008b: 14$]^{5}$.

Problematyczność „filmowego aktu pojednania” próbował uświadomić chyba jedynie autor plakatu reklamującego Po-lin. Plakat przedstawia dwie młode kobiety - identyczne - zwrócone do siebie twarzą w twarz, a więc ukazane widzowi z profilu. Obie mają w uszach kolczyki. Jedna w kształcie krzyża, druga w kształcie gwiazdy Dawida. Twarze dziewczyn różnią się kolorem. Żydówka jest sportretowana w czerni i bieli. Rozumiemy, że należy do minionej epoki. Oczy postaci przesłania napis: „Przed drugą wojną światową żyło w Polsce 3,5 miliona Żydów. Tu rodzili się i umierali, modlili, kochali i cierpieli. Tu była ich Ojczyzna. Po-lin". Plakat istnieje również w wersji równoległej, gdzie postaci są odwrócone do siebie plecami. Ta oboczność sugeruje istnienie co najmniej dwóch różnych wersji opowieści o ziemi Po-lin. Figura bliźniaczego „siostrzeństwa”, partnerstwa i dialogu została tym sposobem opatrzona zastrzeżeniem - nie wiemy, na ile intencjonalnie ${ }^{6}$.

Dla recenzentów sprawa jest znacznie prostsza: Po-lin nawiązuje do wielowiekowego wspótistnienia, wzajemnych więzi, szacunku, dobrego sąsiedztwa oraz życzliwej pamięci. Ma służyć za przesłankę oraz podstawę dzisiejszej tolerancji, dawać odpór jednako

3 Motyw „wzajemnych win” Polaków i Żydów przed, w czasie i po wojnie jest w Polsce bardzo rozpowszechniony i wymagałby osobnego studium. Jako przykład „win żydowskich” wymienia się zwykle Katyń i stalinizm (lub w ogóle komunizm). Jednym z najdonioślejszych przykładów konstruowania symetrii „wzajemnych win” było oświadczenie prymasa Polski w sprawie ujawnienia zbrodni w Jedwabnem. W wypowiedzi z marca 2001 r. kardynał Józef Glemp stwierdzał: „Sprawa przypomina trochę mord w Katyniu”, po czym pytał retorycznie o przyczyny późniejszego o ponad rok mordu w Jedwabnem [Glemp 2010: 570-573]. Por. krytyka konstruktów symetrii i wzajemności: Żukowski 2001a: 26-27; Żukowski 2001b: 40-42; Janicka 2008: 24-44; Janicka 2010.

4 Zwolenniczką tej wizji wydaje się również sama reżyserka, która tak odpowiada na pytanie, dlaczego jej polscy bohaterowie nie przypominają tych z książek Jana Tomasza Grossa: „Różnica jest podstawowa. Gross pisze o tym, co się działo w czasie wojny i po wojnie, a mój film dotyczy tego, co się działo przed. Pojechałam do tych miasteczek, takich Polaków tam znalazłam i oni w ten sposób ze mną rozmawiali. Nie pytałam ich o to, co się działo w czasie wojny i po wojnie, bo to wiedziałam m.in. z relacji ocalonych Żydów z tych miasteczek, zachowanych w archiwach ŻıH-u" [Dylewska 2008b: 14].

5 Po roku 1989 motyw polsko-żydowskiej wspólnoty cierpienia został zdominowany przez motyw symetrii cierpień równoważnych, lecz osobnych. Proces ten rozpoczął się u progu lat osiemdziesiątych XX w.

6 Por. www.filmweb.pl/film/Po-lin.+Okruchy+pamięci-2008-480047/posters (dostęp z 13 czerwca 2011). 
antysemityzmowi i tzw. antypolonizmowi ${ }^{7}$. Wydobycie pozytywnych stron tradycji i włączenie ich do kanonu kultury jest traktowane przez krytyków jako próba przezwyciężenia nienawistnych stereotypów. Należy szukać tego, co łączy, a nie tego, co dzieli - zdają się mówić recenzenci. Choć nie obywało się bez tarć, w polsko-żydowskiej historii przeważało to, co dobre i wartościowe. Może nie idylla, ale przynajmniej dobrosąsiedzka codzienność, którą można i należy przeciwstawiać przemocy oraz nienawiści. „Reżyserka drobiazgowo odtwarza świat przedwojennych Żydów polskich, dla których Rzeczpospolita była prawdziwym i jedynym domem, ojczyzną, ziemią obiecaną" - pisał Piotr Kletowski w „Tygodniku Powszechnym”. „Dylewska, wbrew wypracowywanym przez modnych historyków tezom, pokazuje, że możliwe było harmonijne współżycie między Żydami i Polakami, nawet wówczas, kiedy cieniem na ich relacjach kładł się - faktyczny, ale przecież nie jedyny i nie wyjątkowy - polski antysemityzm" [Kletowski 2008: 32] ${ }^{8}$.

Przyjrzyjmy się filmowemu obrazowi tego harmonijnego współżycia.

\section{Sytuacja komunikacyjna: qui pro quo}

Film Po-lin został zbudowany z przekazów, które należą do dwóch uniwersów komunikacyjnych: żydowskiego i polskiego. Te same teksty i obrazy mają inne znaczenie w każdym z nich. Jolancie Dylewskiej udało się tymczasem uzyskać efekt harmonii dzięki zatarciu wynikających stąd różnic. Diametralna zmiana sytuacji odbioru i jej konsekwencje umykają naszej uwadze. Ceną jest zafałszowanie: gesty i słowa wypowiedziane przez Żydów do Żydów występują w funkcji komunikatu przeznaczonego przez Żydów dla polskich odbiorców - komunikatu, na którego podstawie wyciąga się wnioski o relacjach łączących polskich i żydowskich sąsiadów.

Dylewska używa filmów dokumentalnych nakręconych przez żydowskich emigrantów, którzy w latach trzydziestych XX w. przyjeżdżali ze Stanów Zjednoczonych odwiedzić krewnych w Polsce. Materiały te są pamiątkami rodzinnymi. Filmowcy-amatorzy nakręcili je dla bliskich i przyjaciół na emigracji. Mieszkańcy żydowskich miasteczek znali ludzi, którzy stali za kamerą, i wiedzieli, dla kogo są przeznaczone rejestrowane obrazy. Sytuacja określała na równi zachowanie fotoamatorów i ich bohaterów. Konwencja pamiątkowych zdjęć wyznaczała temat: rejestrowano nie tyle codzienność, ile atmosferę święta, jakim są odwiedziny dawno nie widzianych krewnych, przyjaciół czy znajomych, postrzeganych z reguły jako ci, którym się powiodło. Stąd zachowanie filmowanych osób: są życzliwie zainteresowane kamerą i dobrze nastawione do operatorów. Udziela im się pogodny nastrój. Pozdrawiają tych, którzy będą ich oglądać za oceanem, uśmiechają się.

7 Skądinąd „antypolonizm” jako konstrukt i fantazmat będący częścią antysemickiego pakietu, żywego w polskiej kulturze, zasługuje na osobną monografię.

8 „Modni historycy” to - jak możemy się domyślać - Jan Tomasz Gross oraz kierowany przez Barbarę Engelking zespół Centrum Badań nad Zagładą Żydów przy Instytucie Filozofii i Socjologii PAN. Dodajmy, że celem reżyserki nie była polemika z badaczami: „Moją intencją nie była dyskusja z Grossem, bo z faktami się nie dyskutuje” [Dylewska 2008b: 14] 
Chcą pokazać się z dobrej strony - świąteczny czas nie sprzyja myśleniu o problemach i troskach. Widać to nawet w ujęciach biedoty, żebraków czy miejscowych szaleńców.

Uśmiech do kamerzysty z tej samej społeczności to jedno. U Dylewskiej uśmiech ten zmienia jednak sens. Staje się pozdrowieniem, które mniejszość kieruje do członków większościowej grupy dominującej. Reżyserka nie opatruje zdjęć archiwalnych żadnym problematyzującym komentarzem. Przeciwnie, zdaje się umacniać komunikacyjne nieporozumienie. Na początku filmu pojawia się plansza informująca o pochodzeniu archiwalnych taśm: „Bieg historii sprawit - czytamy - że amatorskie materiały kręcone niewprawną ręką, często przez nieznanych autorów, ocalają dla nas skrawki nieistniejącego świata Żydów polskich” [podkreślenie E.J., T.Ż.] . „My” oznacza polską ekipę filmową, polskich widzów i - najpewniej - Polaków w ogóle.

Wytworzony w ten sposób przekaz stał się ważnym elementem dyskusji, która trwa w Polsce nieprzerwanie od ukazania się książki Sąsiedzi Jana Tomasza Grossa w 2000 r., a została zapoczątkowana tekstem Biedni Polacy patrzą na getto Jana Błońskiego z 1987 r. Twórcy filmu świadomie zabrali głos w publicznej debacie, przywołując na świadków Żydów z archiwalnych taśm.

Fakt ten ma ważne konsekwencje. Podstawą „filmowego aktu pojednania” międzygrupowego, o którym tak chętnie piszą recenzenci, okazuje się brak międzygrupowej komunikacji. Pierwotny kontekst nadawczy i odbiorczy wyłącza zupełnie problem relacji z chrześcijanami. Głos, z którym ma do czynienia grupa dominująca, nie jest więc głosem w sprawie, o której rzekomo chciałaby rozmawiać. Ze zdjęć wykorzystanych przez Dylewską nie dowiadujemy się nic o tym, co żydowscy mieszkańcy sztetli mieli do powiedzenia o polskich sąsiadach. Twórcy filmu pominęli to pytanie. Stworzyli za to całość, która wypacza sens żydowskich komunikatów.

Manipulacja polega bowiem nie tylko na tworzeniu pozorów rozmowy przy faktycznym odebraniu głosu członkom mniejszości. Współczesny materiał obudowujący żydowskie zdjęcia archiwalne sprawia, że Żydzi zdają się mówić. Mówią jednak to, co włożyła im w usta polska reżyserka, która jednocześnie zadbała, żeby nie mogli powiedzieć o grupie dominującej nic rzeczywiście własnego. Filmowe obrazy sztetli i zawarte w nich komunikaty stają się częścią całości, nad którą niepodzielnie panuje polski narrator. Żydzi zostają ubezwłasnowolnieni. Są instrumentem polskiej narracji o nich samych i o tym, jak traktowała ich chrześcijańska większość.

9 Motyw powraca w rozmowie reżyserki z dziennikarką „Gazety Wyborczej”. Katarzyna Bielas: „Bohaterowie amatorskich, nakręconych przed wojną home movies [...], podchodzą do kamery, uśmiechają się, patrzą n a m w oczy [podkreślenie E.J., T.Ż]. Uderza przyjazna, pogodna atmosfera”. Jolanta Dylewska: „To samo czułam, kiedy patrzyŁam po raz pierwszy na te filmy w rozmaitych archiwach na świecie, i to właśnie uczucie chciałam zachować dla przyszłych widzów" [Dylewska 2008b: 11]. 


\section{Harmonia wspomnień i jej kurator-dyspozytor}

Zafałszowanie sięga głębiej, poza samą sytuację odbioru. Nadrzędna perspektywa grupy dominującej została wpisana w strukturę Po-lin. Żydowski świat widzimy oczyma „świadków”: Polaków, którzy znali i którzy wspominają dawnych sąsiadów. Materiał archiwalny nie pojawia się od razu. Opowieść wychodzi od osób, które pamiętają Żydów i mówią o ich „zniknięciu” oraz o pozostawionej przez nich pustce.

Dylewska wprowadza zdjęcia archiwalne taką oto współczesną sekwencją: jedna z dwóch Polek mówi, że Żydzi już jej się nie śnią, choć kiedyś wracali w snach. Następnie pyta o sny swoją towarzyszkę. Najazd kamery na twarz drugiej kobiety. Jej oczy są nieobecne, skupione na czymś dalekim, jakby nie z tego świata. Obraz filmowy podąża za tym spojrzeniem. Pojawiają się zbliżenia detali architektonicznych, najpierw nieostre, po chwili wyraźniejące. Widzimy drzwi, bramy domów, ściany. Nie ma tylko ludzi, choć zza kadru słychać już muzykę stylizowaną na muzykę żydowską, szmery imitujące odgłosy żydowskiej ulicy i głos Piotra Fronczewskiego, który czyta zaczerpnięte z żydowskich „ksiąg pamięci” wspomnienia o żydowskich mieszkańcach miasteczka ${ }^{10}$. Otchłanny głos aktora barwą i intonacją przypomina bas słynnego hipnotyzera i uzdrowiciela-celebryty, Anatolija Kaszpirowskiego. Wreszcie pojawiają się i oni: Żydzi, przywołani z nicości dzięki archiwalnym zdjęciom. Zbliżają się do kamery - a więc do „nas”. Podchodzą z głębi kadru. Uśmiechają się nieśmiało.

„Świadkowie” - Polacy filmowani są w dwóch konwencjach. Wydaje się, że Dylewska wybiera przede wszystkim styl dokumentu: pokazuje polskich bohaterów w miejscach, gdzie żyją i pracują, w swobodnej rozmowie ze stojącym za kamerą reporterem. Notuje ich wspomnienia i emocje. W momentach decydujących dla narracji przechodzi jednak do konwencji psychologizującej - stosuje zbliżenia, które wypełniają cały kadr, kamera przypatruje się oczom jakoby zatopionym w przeszłości. „Po rozmowach stawialiśmy z operatorem Józkiem Romaszem przed nimi kamerę - opowiada reżyserka w wywiadzie dla internetowego pisma «Stopklatka» - i prosiłam, by patrząc w obiektyw, myśleli o jakimś bliskim żydowskim sąsiedzie z tamtego czasu. Bo wierzę, że obiektyw przenosi nie tylko to, co widzialne..." [Dylewska 2008a]. Dylewska świadomie sugeruje obrazem „głębię duchową" i uwzniośla polskich rozmówców.

Dodatkowo reżyserka zakłada - a ściślej: wytwarza - tożsamość polskich i żydowskich wspomnień, bo archiwalne zdjęcia żydowskich fotoamatorów w jej ujęciu okazują się materializacją i zarazem rękojmią autentyczności pamięci Polaków. Przeszłość ma wciąż trwać w „świadkach”, których w porządku symbolicznym umieszczono po tej samej stronie, co ofiary. Jak już mówiliśmy, przyświadczające uśmiechy Żydów ze zdjęć nakręconych w latach trzydziestych nie są adresowane do „nas”. Polski kurator-dyspozytor wie jednak lepiej.

10 Jest to efekt konformizującej perswazji, której uległa autorka filmu: „W pierwszej wersji komentarz miała czytać kobieta. Myślałam o Mai Komorowskiej, niestety okazało się, że w tym czasie jest zajęta. To producent zaproponował Piotra Fronczewskiego. Powiedział: «Jolu, czy zdajesz sobie sprawę, że najważniejsze teksty historii ludzkości czytali zawsze mężczyźni?» Nie wiedziałam, co odpowiedzieć...” [Dylewska 2008a]. 
Gdy w cytowanym wywiadzie dla „Stopklatki” pada pytanie o antysemityzm, dowiadujemy się, że nie był to - i nie jest - problem marginalny. Dylewska zaznacza jednak, że w polskich relacjach „więcej było tego dobrego. Oczywiście były też pogromy - dodaje. - Ale ja ten film robiłam przede wszystkim po to, żeby przywrócić Żydów zbiorowej pamięci. Z drugiej strony też dla tych, którzy ocaleli z Zagłady. Pomyślałam, że może będzie im miło, gdy ktoś powie, tak jak pani Józefa w filmie - że bez nich zrobiło się jakoś tak pusto i smutno. Uważałam, że to ważne, by mogli usłyszeć te słowa” [Dylewska 2008a]. Mamy tutaj do czynienia ze świadomym reżyserskim wyborem. Dylewska decyduje, że będzie pokazywać „to, co dobre”. Jednocześnie zaś rozstrzyga, że to, co pokazuje, decydowało o atmosferze polsko-żydowskich miasteczek. „Przywrócenie Żydów zbiorowej pamięci" odbywa się w związku z tym na szczególnych zasadach.

Wrażenie polsko-żydowskiej harmonii wspomnień zostaje wzmocnione zestawieniem dwóch nostalgii. Nostalgię polską wytwarza sama Dylewska sposobem filmowania: malowniczym fotografowaniem śladów, psychologizującym portretowaniem rozmówców i usuwaniem objawów antysemityzmu. O polską nostalgię jest tym łatwiej, że nie wymaga ona żadnego działania, żadnej rewizji przyzwyczajeń i przywiązań. Rozmówcy Dylewskiej wiedzą, że są pod tym względem bezpieczni: polska większość zadbała o to, by udaremnić możliwość realnego spotkania i realnej komunikacji. Nieliczni Żydzi, którzy uszli z życiem, salwowali się ucieczką. Wymordowanych od dawna już nie ma, niczego od Polaków nie chcą, nic nie mówią, są tylko projekcją wspominających ${ }^{11}$. Projekcją, która łączy się z czasami młodości, a tej przecież zawsze szkoda. Jeden z polskich bohaterów powtarza melancholijnie pod koniec filmu: „Wszystko przemija...”. Ta uniwersalna mądrość jest bezwzględnie prawdziwa. Można się z nią tylko zgodzić: Panta rei. Tempus fugit. Où sont les neiges d'antan!

Nostalgia żydowska to przede wszystkim nostalgia „ksiąg pamięci”, publikowanych przez ziomkostwa Żydów polskich na obczyźnie. Tworzyli je ocalali dla innych ocalałych. Opisywali dla siebie nawzajem zamordowany żydowski świat, w którym polscy sąsiedzi właściwie się nie pojawiają ${ }^{12}$. Dylewska wybiera z tych opowieści fragmenty utrzymane niemal w stylistyce baśni, którą podkreśla dodatkowo namaszczona, hieratyczna interpretacja Piotra Fronczewskiego. Baśń opowiada o starych, dobrych czasach. Pomija tylko to, że były one dobre nie ze względu na życzliwość polskiej większości i godne warunki egzystencji, lecz ze względu na to, że wszyscy jeszcze żyli.

W Po-lin zestawiono obie te nostalgie. Powstaje wrażenie, jakby wychodziły sobie naprzeciw. Tymczasem żadna z opowieści nie przekracza granic własnej wspólnoty. Nie

11 Recenzent „Gazety Wyborczej” pisze zgodnie z prawdą, tyle że nie dostrzegając drugiego dna własnych słów: „Uśmiechają się. Nikogo nie winią, niczego od nas nie potrzebują. To oni nam są do czegoś potrzebni” [Sobolewski 2008: 13].

12 „O ile w częściach dotyczących okresu międzywojennego znajdujemy stosunkowo niewiele szczegółów na temat kontaktów z ludnością chrześcijańską, w partiach dotyczących wojny i okresu powojennego tych informacji jest znacznie więcej i obejmują przeróżne postawy Polaków. [...] Lektura żydowskich ksiąg pamięci może być bardzo pouczająca dla polskiego czytelnika, którego zawarte w nich teksty nierzadko zaskoczą odmiennym spojrzeniem czy wręcz ostrością formułowanych sądów. Należy pamiętać, że większość ksiąg była pisana niedługo po wojnie, kiedy społeczność żydowska w Polsce, tak ciężko doświadczona w czasach Zagłady, dodatkowo została dotknięta falą antysemityzmu, której ukoronowaniem był pogrom kielecki w lipcu 1946 roku" [Adamczyk-Garbowska 2009]. Por. także [Adamczyk-Garbowska, Kopciowski, Trzciński (opr.) 2009]. 
dochodzi do żadnego spotkania. Szczególnie ważne jest to, co dzieje się po polskiej stronie, gdyż grupa dominująca, mówiąc o mniejszości, ustanawia także obraz samej siebie. Stawką polskiego filmu dokumentalnego o Żydach okazuje się wizerunek Polaków.

\section{Rodzinny album wideo $\mathrm{i}$ audio}

Dylewska wpisuje żydowskie zdjęcia archiwalne w polską narrację o polskiej społeczności. Jak już mówiliśmy, archiwalia te pojawiają się na ekranie jako unaocznienie treści wspomnień polskich „świadków”. Towarzyszy temu nadanie filmom żydowskich amatorów szczególnego statusu. Pierwsza sekwencja, zmontowana z materiałów z lat trzydziestych XX w., zbudowana została z ujęć, w których filmowani Żydzi podchodzą z głębi kadru do kamery. Ten gest otwartości i przyjaźni powtarza się aż sześć razy z udziałem różnych osób ${ }^{13}$. Następne cztery ujęcia to fotografie rodzinne. Starsi i dzieci ustawiają się obok siebie i pozują - jak do pamiątkowego zdjęcia. Narracja Po-lin sugeruje, że pozują do fotografii, którą następnie ofiarują „nam”. Trafi ona do zbioru rodzinnych pamiątek przechowywanych przez „świadków”, przekazanych następnie ekipie filmowej i widzom. Dzieje się tak, ponieważ o znaczeniu zdjęć przesądza fakt, czyją własnością jest zbiór fotografii. Jak w przypadku każdego rodzinnego albumu.

Album wydaje się dokumentem par excellence, bo przecież składające się nań zdjęcia to mechaniczna rejestracja rzeczywistości. Sytuacja nie jest jednak aż tak prosta. Kolekcja zdjęć jest faktem kulturowym, opowieścią, która nie może się obyć bez reżyserii, a niekiedy manipulacji ${ }^{14}$. W przypadku zbioru prezentowanego przez Dylewską ważne okazują się trzy połączone ze sobą aspekty prezentacji. Po pierwsze, archiwalne fotografie zostają przejęte przez nadrzędną narrację. Po drugie, wpisują się w konstytutywne dla tej narracji klisze tożsamościowe. Po trzecie, zostają spreparowane w sposób, który sprawia, że nie stawiają oporu kuratorom-dysponentom.

W Po-lin pamiątkowe zdjęcie rodzinne w albumie sąsiadów przypieczętowuje dobrosąsiedzkie przymierze. Niezależnie od własnych intencji, Żydzi zostają wprzęgnięci w polską sagę rodzinną o polskiej genealogii, tożsamości i wyjątkowości na tle Europy. O Paradisus Judeorum. Zza sensów wtłoczonych w archiwalne fotografie przez polską opowieść wyłania się zasadniczy status filmów z lat trzydziestych w Po-lin Dylewskiej: status podporządkowania i dyspozycyjności. Reżyser - nowy właściciel archiwum - przejmuje kontrolę nad wizerunkami, dokonując czegoś, co należy nazwać przechwyceniem, o ile nie kradzieżą.

13 Gest zbliżania się do obiektywu - gest zawierzenia i oddania - dodatkowo wystawia żydowskich bohaterów na przemoc ze strony tych, którzy obejmą w posiadanie naświetlone klisze i użyją ich do własnych celów. Dylewska nie spostrzegła tego niebezpieczeństwa. Wizerunek osób należących do mniejszości - i całej mniejszości - wydała przemocy większości.

14 Fotografie definiują krąg rodziny i przyjaciół, a co ważniejsze, określają status właściciela albumu, który używa obrazów do tworzenia narracji o sobie. Z reguły takiej, jaka mu najbardziej odpowiada i do jakiej aspiruje. Jej budulcem są warianty kulturowych klisz statusu i postaw, czy to będą widoki białego dworku, migawki z wakacji w Nicei na początku wieku, czy zdjęcia ze znanymi osobistościami. Album rodzinny może składać się ze zdjęć prawdziwej rodziny i przyjaciół, choć niekoniecznie. Pod hasłem „Kup sobie przodków!” czeka na nowych właścicieli niejedno archiwum starych fotografii. Bez względu na autentyczność zdjęć, zasada pozostaje niezmienna: ten, w czyje ręce trafiają obrazy, staje się dysponentem ich sensu. Konstruuje z nich swoją genealogię i tożsamość [Sekula 2010: 91]. 
W efekcie większość otrzymuje to, co lubi najbardziej: miłych, zadowolonych Żydów, którzy usłużnie wychodzą naprzeciw polskiej wersji wydarzeń. Unicestwiona zostaje możliwość zobaczenia w niemym materiale pustki, odsyłającej do eksterminacji. Wstrząs, który zmusza do rozpoznania mechanizmów zbrodni i skonfrontowania się z jej społecznym konkretem, żeby - jak pisał Adorno - „myśleć i działać tak, aby nie powtórzył się Oświęcim, aby nie zdarzyło się już nic podobnego" [Adorno 1986: 512-513], rozpływa się w bezproblemowej samoafirmacji polskiej wspólnoty. Ujęcia, w których rzeczywistość sprzed Zagłady konfrontowana jest ze współczesnymi obrazami tych samych, opustoszałych miejsc, zostają natychmiast zagarnięte przez nadrzędną opowieść - harmonijną i nader efektowną formalnie.

Żeby przejęcie obrazów mogło się udać, widz nie może ani na chwilę zostać sam na sam z materiałem pokazanym w formie, w jakiej zostawili go żydowscy autorzy i właściciele. Intelekt i zmysły widza są nieustannie zagospodarowane i formatowane. Do niemych obrazów z lat trzydziestych dodano podkład dźwiękowy, na który składają się wszelkie możliwe odgłosy odpowiadające konkretnym kadrom. Oglądając ulicę, słyszymy kroki i gwar dalekich rozmów. Kiedy na ekranie przechodzi koń, rozlega się stuk kopyt i rżenie. Kiedy pojawia się stacja kolejowa, zza kadru dochodzi gwizd lokomotywy i odgłos ruszającego pociągu. Czarno-białe zdjęcia mają wszelkie cechy amatorskich materiałów archiwalnych - są miejscami nieostre i porysowane, ziarno obrazu jest grube. W zestawieniu z archiwalnym obrazem dźwięk uderza doskonałością techniczną. Jest hiperrealistyczny: hiperczysty i hiperdopracowany. Za sprawą tego kontrastu ścieżka dźwiękowa wyodrębnia się, autonomizuje i przykuwa uwagę jako oddzielne dzieło: konstrukcja autorska.

Dźwięk „ożywia” obrazy. Recenzenci zwracali uwagę, że Dylewska „drobiazgowo odtwarza” świat przedwojennych żydowskich miasteczek [Kletowski 2008: 32] ${ }^{15}$. Dodane odgłosy są częścią operacji „odzyskiwania” przeszłości, podobnie jak zwolnione tempo archiwalnych zdjęć i zbliżenia poszczególnych postaci. Wszystko to zwraca uwagę na pieczołowitość, związany z nią wysiłek i osoby, które go podejmują. Zabieg twórców filmu łączy ich samych, a także publiczność, z polskimi „świadkami”. „My”, dla których zostały ocalone archiwalne materiały, razem „ożywiamy” żydowski świat, wydobywamy go z nicości i przekazujemy następnym pokoleniom. Grupa większościowa reżyseruje tutaj samą siebie.

15 Podobnych głosów jest więcej. Piotr Śmiałowski pisał: Dylewska „zdecydowała się na zabieg, który jest chyba najlepszym pomysłem Po-lin: stare taśmy odtwarzane są w nieco zwolnionym tempie. Podłożono pod nie dźwięki, które do pewnego stopnia współgrają z tym, co dzieje się na ekranie. Dźwięki te nie brzmią jednak zwyczajnie. Mają pewien pogłos, są także nieco zniekształcone. [...] Wszystkie te elementy tworzą wrażenie, jakby słuchało się czegoś w rodzaju klechdy, a sam obraz staje się tym, co moglibyśmy sobie w tym momencie wyobrazić, mając zamknięte powieki" [Śmiałowski 2008: 91].

„Na czarno-białych taśmach odżywa świat, jaki dziś znamy najwyżej z Austerii Kawalerowicza. [...] I jeśli ktoś szermuje hasłami o polskim antysemityzmie, powinien koniecznie obejrzeć ten film. [...] Zachowane na taśmach obrazy, pieczołowicie odtworzone odgłosy, nastrojowa muzyka Michała Lorenca. Ten mądry, pełen tęsknoty i tolerancji film powinien wejść do szkolnego kanonu" [Hollender 2008: A20].

„Jej wzruszający film składa się prawie w całości z pieczołowicie odrestaurowanych fragmentów amatorskich nagrań rejestrujących najzwyklejsze zachowania, ulotne chwile beztroski i szczęścia” [Wróblewski 2008].

„To nieistniejące życie - zapisane na amatorskich, gruboziarnistych, porysowanych filmach, kręcone chwiejną kamerą - zyskuje niesamowitą intensywność. Właśnie na skutek niedoskonałości technicznej taśm ma się wrażenie bezpośredniego kontaktu z żywą rzeczywistością" [Sobolewski 2008: 13]. 
Znika także problem milczenia oglądanych na ekranie osób. Wrażenie obcowania z żydowskim głosem wzmacnia komentarz czytany przez Piotra Fronczewskiego. Na jednej z plansz na początku Po-lin pojawia się informacja: „Ci co przeżyli, pisali KSIĘGI PAMIĘ$\mathrm{CI}$ - SIFREI ZIKARON. Dzięki księgom powstał komentarz do tego filmu”. Wrażenie jest nieodparte: oto żydowskie ofiary odzyskują głos i wspólnie z polskimi „świadkami” opowiadają o ziemi Po-lin.

Komentarz utrzymany jest konsekwentnie w czasie teraźniejszym ${ }^{16}$. W wywiadzie dla „Stopklatki” Jolanta Dylewska opowiada o wyborze takiej formy gramatycznej: „Hanna Krall [...] dokonała korekty genialnej i zasadniczej dla filmu. Powiedziała: «Jak to? dlaczego w czasie przeszłym? - przecież oni wszyscy jeszcze żyją». Dzięki temu widz może mieć wrażenie, że ten świat jeszcze trwa. Dzięki zachowaniu czasu teraźniejszego ci ludzie są bardziej żywi. Może u kogoś z widzów pojawi się takie wrażenie, że ten świat jeszcze można uratować. Z mojego punktu widzenia to może być ważny wkład emocjonalny widza w ten film" [Dylewska 2008a].

Wypowiedź reżyserki ujawnia problemy związane z pamięcią jako „uobecnianiem”. Pamięć („subiektywne”) ma zostać uwiarygodniona za pomocą obrazu mechanicznego („obiektywne”). Dylewska zdaje się sądzić, że zabieg taki sięga obiektywności: jest nią przeszłość, którą wystarczy przywołać w jej realnym kształcie. W istocie przywoływanie minionego świata jest jego wytwarzaniem. Zasady owego wytwarzania dyktują autorzy narracji historycznej ${ }^{17}$. W przypadku relacji między grupą dominującą a mniejszością problem komplikuje się - szczególnie gdy rekonstrukcja następuje po eksterminacji: wobec Zagłady i długiego cienia Zagłady ${ }^{18}$.

„Uobecnianie” przeszłości w Po-lin jest próbą wzięcia Zagłady niejako w nawias. Gdy pamięć zatrzymuje się na czasach sprzed eksterminacji w przekonaniu, że da się je ożywić, eksterminacja przestaje być istotną cezurą. Akcent przesuwa się z konieczności przemyślenia mechanizmów ludobójstwa i zachowań grupy dominującej wobec eksterminowanych na kultywowanie pamięci o Żydach sprzed katastrofy, a właściwie większościowych wyobrażeń na ich temat, co nie wymaga korekty zachowań ani przekonań większości.

Dylewska ma świadomość, że sama uczestniczy w „odzyskiwaniu” wymordowanego świata i proponuje podobną rolę widzom, ale nie problematyzuje tego procesu. W efekcie nic nie chroni bohaterów obrazu przed władzą jego kuratora-dyspozytora. Pamięć wytwarza podobizny nieobecnych, które zasłaniają swoje pierwowzory, a widzów oddzielają od rzeczywistości. Powstaje przy tym złudne poczucie obcowania z umarłymi - tym Łatwiejsze i bardziej uspokajające, że poddani są oni większościowej narracji i w żaden sposób nie próbują jej kwestionować. Kiedy opowieść toczy się w czasie teraźniejszym,

\footnotetext{
16 W żadnym razie nie jest to komentarz właściwy konwencji New Documentary, który można by traktować jako dodatkowy głos w dyskusji. Dylewska operuje w Po-lin starannie wytworzonym efektem jednogłośnego współbrzmienia przekazów z różnych źródeł.

17 Zjawisko to opisał wyczerpująco Hayden White, wydobywając decydującą rolę konwencji narracyjnych, za pośrednictwem których kultura, społeczność, a wreszcie historycy postrzegają i porządkują fakty. Narracja historyczna jest w perspektywie White'a nie tyle prostym odbiciem przeszłości, ile wytwarzaniem jej obrazu [White 2010].

18 Sformułowanie oznaczające powojenny antysemityzm [Tych 1999].
} 
jej bohaterowie mogą wydawać się „bardziej żywi”" ale faktycznie zostają ostatecznie uśmierceni. Pamięć zamienia się w fetysz, wokół którego organizuje się fałszywa świadomość grupy dominującej.

\section{5. „Fotografia ojczysta” wczoraj i dziś. Dygresja o estetyce}

Zanim pojawią się twarze i postaci Żydów, oglądamy ślady, które grają rolę pośredników pamięci. Patrzymy na nie z perspektywy zatopionych we wspomnieniach polskich „świadków”. Uważne oko odkrywa detale, które dzięki skupieniu obserwatora zaczynają opowiadać własną historię i ujawniać sens zapisany w architekturze i pejzażu miasteczek. Kamera wychodzi od szczegółu. W pierwszych dwóch ujęciach przypatruje się pomalowanym na olejno deskom, odchodzącej farbie, pęknięciom starego drewna, powoli ogarnia wysłużoną klamkę i okucie, później kuty skobel. W drugiej, dłuższej serii - zawierającej aż 11 niespiesznych ujęć - powiększa kąt widzenia. Zaczyna od dykty, którą zabito stare okno. Zbliżenie jest tak duże, że z początku trudno zorientować się, co przedstawia. Obraz powoli klaruje się. Travelling w górę. Zza dykty wyłania się gwiazda Dawida. Wiemy już, co oglądamy. Teraz następują ujęcia okien, bram, ścian, fragmentów fasad i dachów. Piotr Fronczewski deklamuje wspomnienie o mieszkańcach miasteczka. Wymienia nazwiska i zawody. Rytm montażu pokrywa się z rytmem wyliczania. Ujęcia wychodzące od nieostrego i rozmazanego obrazu, który następnie powoli uzyskuje wyrazisty kształt - powtórzone kilkakrotnie - podkreślają efekt wywoływania wspomnień.

„Kamera filmuje zamknięte drzwi domów, puste ulice - pisał Piotr Śmiałowski w miesięczniku «Kino» - to oczywiście przerysowanie, lecz w zestawieniu z ruchem i ożywieniem widocznym w archiwalnym materiale - ma swoją siłę”. I dalej: „Wszystkie te subtelne środki formalne pozwalają uniknąć mówienia wprost o tragedii Zagłady" [Śmiałowski 2008: 91]. Zawieszenie głosu, przemilczenie i akcentowanie pustki budzą uznanie recenzenta. Wypada jednak zapytać, w jaką konstelację sensów wpisuje się ta strategia.

Poetyka akcentowania nieobecności ofiar Zagłady i przywoływania pozostawionych przez nich rzeczy ma w polskiej kulturze swoją historię. Wystarczy przypomnieć Non omnis moriar Zuzanny Ginczanki, Dzwonki Władysława Szlengla, Jeszcze Wisławy Szymborskiej czy Ballady i romanse Władysława Broniewskiego [Żukowski 2005: 223-243]. Teksty Ginczanki i Szlengla należą do najdrastyczniejszych, jakie napisano w języku polskim. Artyści mówią w nich własnymi słowami, bez cenzury. W Po-lin sens poetyki braku jest odwrotny. Pozwala ona tak spreparować żydowskich bohaterów, żeby bez reszty wydać ich we władanie polskiej narracji „na słodko”. Pustka po wymordowaniu i wygnaniu Żydów nie staje się punktem wyjścia do namysłu nad sposobem jej wypowiadania oraz nad związkiem rodzaju opowieści z przemocą i dominacją większości. Piękno śladów i poetyka harmonii, w której się je filmuje, jest okazją do łatwej zadumy i uogólniającej melancholii.

19 Nawiasem mówiąc, trudno zrozumieć, co miałoby znaczyć to sformułowanie w odniesieniu do ofiar Shoah. 
Kadry przedstawiające detale architektoniczne utrzymano w poetyce wysublimowanej fotografii krajoznawczej. Są piękne, a ich kompozycja nie pozostawia nic do życzenia. Podobną konwencję wykorzystują albumy poświęcone polskiemu pejzażowi i architekturze. Z ich estetyką wiąże się specyficzna definicja polskości oraz sposób traktowania tego, co owa definicja określa jako obce. Wybór konwencji fotografowania lokuje Po-lin wśród przedstawień podobnego typu.

Tradycja, o której mówimy, sięga w Polsce Jana Bułhaka oraz jego programu „fotografii ojczystej”. Etos Bułhakowski charakteryzowała przede wszystkim afirmacja tego, co narodowe, połączona ze swoistą melancholią. Narodowej esencji miał bowiem zagrażać napór modernizacji. Bułhak wielokrotnie powtarzał, że Polska, którą fotografuje - świat dworów, wsi litewskiej czy starego Wilna - odchodzi w przeszłość. Jednocześnie podkreślał, że tam właśnie tkwią korzenie polskiej tożsamości. Program „fotografii ojczystej” opierał się na założeniach niemieckiej Heimatphotographie ${ }^{20}$, powielał jego rozumienie ziemi, narodu i biologicznego typu narodowego.

Bułhak był nacjonalistą. Wszelako z metafor, których chętnie używał, nie wyprowadzał - jak się zdaje - ostatecznych konsekwencji w odróżnieniu od artystów III Rzeszy. Kierując miejskim archiwum fotograficznym w Wilnie, fotografował dzielnicę żydowską i żydowskie cmentarze, podobnie jak wiejskie chaty białoruskie i litewskie. Inność stanowiła dla niego jednak problem. Dla Bułhaka Żyd jest raz „długobrodym patriarchą” [Bułhak 2003: 62], innym razem występuje w takim oto - sporządzonym już w czasie drugiej wojny światowej - opisie: „miasteczko było nędzne, zażydzone i jak wszystkie inne w naszym kraju doprowadzone przez rządy zaborcze do upadku" [Bułhak 2003: 72]. Na przykładzie rozumowania artysty widać, jak przyciągający mit i odpychający stereotyp stanowią awers i rewers etnonacjonalizmu.

Buthak sporządzał wizerunki inności po to, by uzasadnić przekonanie o polskiej wyższości. W książeczce z serii Wędrówki fotografa w słowie i obrazie, w części poświęconej ziemiaństwu pojętemu jako uosobienie polskości, czytamy: „typ budownictwa dworskiego ustalił się w formach tak zdecydowanych, że wznoszono jego wzorem nie tylko siedziby wiejskie, lecz i całe miasteczka, nie wyłączając karczem, sklepów, hal targowych i bóżnic żydowskich" [Bułhak 1936: 17]. Synagoga pojawia się więc w polu widzenia Bułhaka o tyle, o ile potwierdza kulturową wyższość i promieniowanie polskości²1.

Pod warunkiem przejęcia i powtórzenia - a więc potwierdzenia - tego, co „rdzennie polskie", inność ma prawo istnieć obok tożsamości. Ta zaś rodzi się z obcowania z ziemią, która pozostaje w najściślejszym sensie polska i szlachecka, co Bułhak opisuje w takim, na przykład, fragmencie, jednym z wielu podobnych: „Jak na pewnych gatunkach drzew przebywają określone odmiany owadów, jak pewne obszary leśne i gruntowe są terenem

20 Na temat związków „fotografii ojczystej” z nazizmem w Niemczech, sanacją w II Rzeczpospolitej oraz nacjonalistyczną legitymizacją władzy komunistycznej w PRL zob. Szymanowicz 2009.

21 Nie jesteśmy zwolennikami dociekań, co było pierwsze - jajko czy kura - zwłaszcza w etnonacjonalistycznym kontekście. Nie zdziwiłoby nas jednak, gdyby pierwsze dwory w „rdzennie polskim” stylu z „dachem polskim” wznosili - według własnego pomysłu - żydowscy cieśle. 
bytowania tych, a nie innych typów zwierzęcych, podobnież utworzyły się ściśle zespolone z sobą kompleksy życia roślinnego i ludzkiego. Jednym z takich przyrodzonych kompleksów jest osobliwy polski organizm psycho-biologiczny, nie mający podobnych sobie w całej Europie - dwór wiejski i osoba zamieszkującego ten dwór szlachcica polskiego na kresach" [Buthak 1936: 5] ${ }^{22}$.

Bułhak jednocześnie dostrzega i pomija odmienność ${ }^{23}$. W ramach feudalnych stosunków dworskich odrębność faktycznie można było ignorować. Pozostawała swojska, o ile nie domagała się równych praw. Bez imienia własnego mogła trafić nawet w pobliże centrum polskiej tożsamości, do opowieści o związku ziemi i polskości. Bułhak pisał o dworze, że jego „formy mają najzdrowszy i jedyny słuszny punkt wyjścia, bo naszą staroświecką, chłopską chatę" [Bułhak 1936: 17]. Z całego wywodu wynika, że "nasza” znaczy tu „rdzennie polska”, choć w rzeczywistości chodzi o chatę białoruską.

Kiedy tego rodzaju zawłaszczenie jest już niemożliwe, a inność zaczyna domagać się własnego miejsca i uznania różnicy, w odwodzie pozostaje zabieg asymilacji podobny jak w przypadku synagogi: to, co odrębne, potwierdza panowanie polskości i służy polskiej publiczności za lustro, w którym z pełną afirmacją podziwia ona własną wyidealizowaną podobiznę. Dwór - pisał Bułhak - „promieniował na okolicę - słowem polskim i słowem bożem, że jeśli dzisiaj z kilku miljonów białorusinów jeden milion czuje się całkowicie Polakami i stał się nimi dobrowolnie, bez najmniejszego przymusu, to jest to wyłączną zasługą dworu polskiego i kościoła, przez ten dwór zbudowanego i utrzymywanego" [Bułhak 1936: 27-28] $]^{24}$.

W podobnym duchu widzą odrębność spadkobiercy tradycji Bułhaka. Starają się oni uchwycić i ocalić domniemaną istotę polskości, zagrożoną „wczoraj przez Moskwę, dziś przez Brukselę". W albumie Polesie Krzysztof Hejke tropi zapomniane ślady polskości na tak zwanych Kresach [Hejke 2009] ${ }^{25}$. Tak jak Bułhak, fotografujący odchodzące w prze-

22 Tego rodzaju stwierdzeń znajdzie się w twórczości pisarskiej Bułhaka z lat trzydziestych znacznie więcej. Fotograf odróżniał szlachcica przede wszystkim od człowieka miejskiego, kupca, pośrednika czy fabrykanta, który stracił łączność z ziemią - ojczyzną. Różnica ta powstawała, jego zdaniem, na tle rasowym. Przykładem wywód na temat ziemianina kresowego o wyraźnie antysemickim podtekście: „nie jako pasożyt przybłęda, wybierający źródło największego zarobku, osiadł on na ziemi i rządził jej dostatkami. [...] Stał się panem w najlepszym znaczeniu tego pojęcia, panem ziemi rodzącej, obfitej i pięknej. A takie państwo obudza uczucia prawe i dobre [...]. Są to uczucia, które dać może jedynie tradycja i rasa, to wielkie słowo, zbyt często obecnie lekceważone w stosunku do ludzi, aczkolwiek bardzo poważnie traktowane w odniesieniu do zwierząt”. I nieco dalej: „Przez kilkaset lat szlachcic sam jeden bronił ojczyzny i odpierał jej wrogów. Nie brali w tym udziału ani chłop, ani mieszczanin, tem mniej niemiecki rzemieślnik-kupiec lub żydowski handlarz-pośrednik" [Bułhak 1936: 12-13].

23 W rodzinnym majątku Bułhaka w Ostaszynie mówiono po polsku i po białorusku, „narzecze ludowe przenikało we wszystkie pory życia dworskiego, mówili nim biegle nie tylko dorośli, ale i dzieci prędko się go nauczyły, obcując ze służbą i robotnikami” [Bułhak 2003: 54]. I dalej: „Lubiliśmy tę mowę, ale nie wiedzieliśmy, że ktoś ma pretensje nazywać ją białoruską, gdyż nazwa ta nie istniała wcale u nas i nie była ani znana, ani używana przez chłopów" [Bułhak 2003: 56].

24 Cytat z zachowaniem oryginalnej pisowni - także wielkich i małych liter w nazwach narodów. Jak wyglądała ta dobrowolność „bez najmniejszego przymusu”, można przeczytać np. w rozdziałach Na Wileńszczyźnie i Administracja w: Miłosz 1999: 235-263, 393-418.

25 Fotograf jest także autorem wielokrotnie nagradzanego albumu: Polska romantyczna [Hejke b.d.]. We wstępie Marek Rostworowski pisze: „Teraz jednak chcę jeszcze zwrócić uwagę na polskość drogi, jaką szedł Krzysztof Hejke. Stosunek do natury ukazany w tym albumie jest zakorzeniony w kraju autora, i jest wyrazem emocjonalnego podejścia do świata. [...] Album będący owocem tej kontemplacji może przyczynić się do zauważenia, pokochania i kultywowania własnego miejsca na ziemi" [Hejke b.d.: 13-14]. W tym sensie Polska romantyczna miała się różnić od prac fotografów amerykańskiego „National Geographic”, którzy jakoby rejestrowali rzeczywistość „okiem raczej bystrym i chciwym niż kontemplatywnym" [Hejke b.d.: 13-14]. 
szłość dwory, wyrusza na poszukiwanie narodowego mitu [Hejke 2009: 76-77, 102-103]. Współczesna Białoruś służy mu za negatywny punkt odniesienia. Na tle biedy i zacofania rysuje się wspomnienie kwitnących polskich pałaców i dworów oraz zasobnych wsi w ich sąsiedztwie. Obiektyw Hejkego - tak jak kamera Dylewskiej - skupia się na szczegółach. Kadry fotografa są harmonijne i piękne. Tak jak Bułhak przypatruje się fakturom ścian ${ }^{26}$. Fotografuje okna opustoszałych domów, czarne drewniane chaty z wiankami cebuli pod okapem ${ }^{27}$. Zbliżenia ujawniają ślady polskości: zardzewiałe tabliczki z napisem „ubezpieczono” - „ślad działalności przedwojennej polskiej administracji, która wprowadziła powszechne ubezpieczenia również dla wiejskich zagród" [Hejke 2009: 136-137] - albo wyblakłe polskie napisy reklamowe na murach w Pińsku. W aurze nostalgii za dawną, idealną Polską pojawiają się staruszki w poleskich, białoruskich strojach ludowych, a obok zdeklasowanej szlachcianki z zaścianka możemy zobaczyć i polskiego Żyda z Pińska, żołnierza 16. Pułku Ułanów w Bydgoszczy odznaczonego medalem za kampanię wrześniową.

Użycie odmienności jako lustra, w którym przegląda się większość dominująca, jest silnie związane z konwencją fotograficzną, z której korzysta Jolanta Dylewska. Kadry ze śladami istnienia żydowskich twórców i mieszkańców sztetli mają w sobie tyle nostalgicznego piękna i harmonii, że pozwalają - bez przeszkód i mimo wszystko - zadomowić się w pożydowskim domu i w melancholijnym obrazie, który ani razu nie uwalnia się spod kontroli kuratora-dyspozytora. Nie stwarza żadnych problemów. Uspokaja. Formalna doskonałość nie dopuszcza w pole widzenia niczego, co mogłoby zmącić samoafirmację i samozadowolenie, popsuć bezrefleksyjne zakorzenienie Polaków w polskości.

\section{Wytwarzanie „świadka” i „strażnika pamięci”: perpetuum mobile}

Na pierwszy rzut oka może się wydawać, że Po-lin poszerza formułę „fotografii ojczystej”. Wprowadza przecieź ślady tego, co odmienne, żydowskie. Ważna jest jednak przede wszystkim relacja łącząca ślady po Żydach i Polaków. Jolanta Dylewska definiuje ją w jednej z otwierających film sekwencji o pożydowskim domu.

Kamera znów zaczyna od zbliżeń okien, drzwi i ścian. Zatrzymuje się na klamkach i zamkach. Wchodzi do wnętrza. Zagląda do pokoju z obrazem na ścianie. Ustawienie ostrości skupia uwagę widza na framudze i przybitej do niej mezuzie, ale możemy się domyśleć, że na ścianie wisi oleodruk z postacią Najświętszej Marii Panny. Zza kadru dochodzi głos właścicielki: „W tym domu zostało błogosławieństwo żydowskie. To było na każdych drzwiach, tylko jedne się zachowały. To jest tego domu pamiątka i tak musi być”. Słyszymy tykanie zegara, który pojawia się w kadrze w dużym zbliżeniu. W tle obraz

26 W książce pt. Jan Buthak (1876-1950). Fotografik znajduje się wiele zbliżeń fragmentów architektury. Najbardziej pokrewne poetyce Dylewskiej są takie zdjęcia, jak: Wilno. Zautek szlachecki (1919 r.) czy Wilno. Okno domu przy ul. Rudnickiej (ok. 1913 r.) [Jurkowlaniec (red.) 2007: odpowiednio 424, 320].

27 Niedawny redaktor artystyczny „Gazety Polskiej” wyznaje: „Od początku szukałem moich wyobrażeń piękna, wymarzonych krajobrazów przede wszystkim w Polsce. Może to dziś niezbyt modne czy wręcz banalne, ale ja po prostu kocham swój kraj i jest mi on najbliższy. [...] Szalenie trudno jest tak korzystać z dobrodziejstw dzisiejszej techniki, by utrwalić na kliszy to, co się chce, a nie to, co się widzi. [...] Dość często tam jeżdżę, na Kresy. Szukam takich zegarów, które przypominają księżyc, drzew, które zwijają gałęzie w dłonie, ludzi, którzy przyjmują nieznajomego tak, jakby nikt ich nie rozczarował. Mam całe stosy fotografii kresowych" [Hejke 2005: 74]. 
Matki Boskiej Częstochowskiej na domowym ołtarzyku, wydobyty zmianą głębi ostrości. Kadr jest ciepły. Twarz Madonny przysłaniają rozmyte kształty kwiatów. Kwintesencja polskiego domu. Głos Piotra Fronczewskiego, który przed chwilą odczytywał żydowskie „księgi pamięci”, obwieszcza z namaszczeniem: „To są ostatni z dziesiątków pokoleń Polaków, którzy przez kilkaset lat żyli obok polskich Żydów. Ostatni świadkowie, którzy łączą nas z życiem tamtych. Ostatni”. Na ekranie pojawiają się skupione twarze Polaków. Zbliżenia. Tykanie zegarów. Za chwilę „świadkowie” zaczną wspominać28.

Dylewska gra ikonami tożsamości. Ślad po zamordowanych żydowskich właścicielach i mieszkańcach domu - mezuza na framudze drzwi - wspótistnieje harmonijnie z archetypicznym znakiem polskości: ołtarzykiem domowym i wizerunkiem Matki Boskiej Częstochowskiej. Sposób filmowania podkreśla harmonię. Przejście jest płynne, obraz utrzymany w intymnym i swojskim nastroju, którego nic nie mąci. Odkrywamy istotę polskiej postawy: jest nią opieka nad śladami po nieobecnych. Poetyka wypowiedzi („To było na każdych drzwiach, tylko jedne się zachowały”) przywodzi na myśl ekspertyzy fachowców od prehistorii (,Do naszych czasów zachowały się jedynie fragmenty szkieletu archeopteryksa”). Unieważnia więc pytanie o to, co stało się z Żydami oraz ich ruchomą i nieruchomą własnością. Ot, przeszedł kataklizm, z którym nie mamy nic wspólnego, i pochłoną ${ }^{29}$. Nad wyraz dobrze zatem świadczy o Polakach, że tak się troszczą z własnej woli o przetrzebione okrutnie żydowskie pozostałości ${ }^{30}$.

Opieka ta zdaje się akceptowana i konsekrowana przez żydowskich umarłych. Zdanie „W tym domu zostało błogosławieństwo żydowskie” jest dwuznaczne. Odnosi się do pergaminowego zwitku z fragmentem Tory, ale można je rozumieć i tak, że błogosławieństwo dawnych właścicieli - czy w ogóle żydowskiej społeczności - wciąż obejmuje dom i jego nowych mieszkańców. Interpretację tę zdaje się potwierdzać ścieżka dźwiękowa. Piotr Fronczewski, który użycza głosu żydowskiej wspólnocie, orzeka - niejako w jej imieniu że mamy do czynienia z „ostatnimi świadkami”. Co więcej, chodzi o „strażników pamięci” po wymordowanych. „To jest pamiątka tego domu i tak musi być” - mówi mieszkanka pożydowskiej posesji, ustanawiając symboliczny status wszystkich występujących w filmie Polaków jako ludzi, którzy wzięli na siebie zadanie ocalenia pamięci o żydowskich sąsiadach i są w pełni świadomi swej misji.

Wprowadzenie kategorii „strażnika pamięci” i „świadka” pozwala zasugerować wspólnotę polsko-żydowską i zrobić z występujących Polaków kogoś, kto z nadania samych Żydów pieczołowicie strzeże pamiątek po nich, okazując tym samym lojalność dawnym sąsiadom. Polacy okazują się godnymi spadkobiercami żydowskiego dziedzictwa.

28 Recenzenci nie pozostali obojętni wobec tej konstrukcji: „Unikając patosu, wolno mimo wszystko stwierdzić, że dokument Po-lin zachwyca, przyciąga, ponieważ jest próbą pokazania życia, które kiedyś istniało. [...] Z drugiej strony film stanowi hołd dla samej postaci świadka [...]. Polscy świadkowie Dylewskiej to żywe przykłady przeszłości, wspomniane już wyżej «okruchy zbiorowej pamięci», którzy dzięki reżyserce poprzez archiwalny obraz wracają do swojego dzieciństwa po to, aby świadkować" [Ostrowska 2009: 72].

29 Dylewska nie wspomina, że nawet w biednych rodzinach mezuzy były zwykle srebrne i stanowiły łakomy kąsek dla osób rabujących żydowskie domy.

30 Przedmiotem naszej analizy jest konstrukcja filmu Po-lin. Znamy osoby, które czyniąc się strażnikami żydowskich śladów i śladów śladów, znalazły się poza nawiasem własnej społeczności. Ich opowieści nie są kojące. 
Rozumiemy teraz, dlaczego to, co polskie, i to, co żydowskie, współistnieje w pełnej harmonii. Obie wspólnoty - mimo wszystkich różnic - łączy wszak to samo posłannictwo: przechowywanie pamięci zagrożonej upływem czasu. Tykają zegary. Spojrzenie Najświętszej Marii Panny ogarnia troskliwie mezuzę.

Obraz polskiej społeczności i stosunków polsko-żydowskich zbudowany jest na przemilczeniu podstawowych faktów i pytań. Oglądamy pożydowski dom. Nie dowiadujemy się jednak niczego o okolicznościach, w jakich przeszedł w ręce nowych właścicieli. Tymczasem w skali społecznej okoliczności te są niezwykle ważne, nawet jeśli rozmówcy Jolanty Dylewskiej są na wskroś uczciwymi ludźmi. W opowieści o żydowskim świecie sprzed wojny nie da się pominąć Zagłady i postawy strony aryjskiej wobec eksterminowanych Żydów, jak również stosunku Polaków do Żydów po wojnie. Szczególnie jeśli „strażnikami pamięci” nazywamy ludzi, którzy żyją w pożydowskich domach.

Dylewska zaciera ten problem ${ }^{31}$. Unika mówienia o Zagładzie, a jednak mówi o niej. Słowo „świadek” w dzisiejszym języku stanowi jedno z podstawowych pojęć opisujących eksterminację Żydów [Hilberg 2007] ${ }^{32}$. Reżyserka używa go, mając na myśli czasy sprzed 1939 r. Jednocześnie zaś przywołuje znaki Shoah - rzeczy pozostałe po zamordowanych. Jeśli w pożydowskim domu mezuza współistnieje z jasnogórską ikoną, to znaczy, że w czasie wojny na granicy polsko-żydowskiej nie wydarzyło się nic niepokojącego.

Tymczasem przejmowanie żydowskich rzeczy przez Polaków - by nazwać rzecz eufemistycznie - było zjawiskiem masowym. Odbywało się w sytuacji, która w skali grup społecznych nie pozostawiała miejsca na bycie świadkiem. Uniemożliwia też nazwanie polskiej społeczności strażnikiem pamięci bez dodatkowych wyjaśnień. Świadek to ktoś, kto przygląda się z boku, nie uczestniczy w sytuacji i nie ma wpływu na to, co się dzieje. Określenie takie mija się z rzeczywistością z trzech powodów.

Po pierwsze, życie lub śmierć próbujących się ratować Żydów zależały od postawy strony aryjskiej. Od czynnej pomocy, bez której nie sposób było przeżyć. Przede wszystkim jednak od bierności, która pozwalałaby zniknąć w polskim otoczeniu ${ }^{33}$. W skali społecznej brakowało i jednej, i drugiej. Polskie miasto i wieś były dla ukrywających się Żydów

31 Problem polskiej przemocy wobec Żydów pojawia się na marginesie opowieści i nie zostaje rozwinięty. Najpierw w części poświęconej organizacjom społecznym i samoorganizacji wspólnot żydowskich wspomina się o syjonistach: „Narasta antysemityzm i syjonistyczne organizacje skautowe przygotowują młodzież do emigracji do Palestyny”. Następna sekwencja przenosi widzów do Kolbuszowej. Jeden z jej mieszkańców zapewnia: „Współżycie Polaków i Żydów przed wojną było zupełnie normalne. No, świadczy o tym herb kolbuszowski, który właśnie pokazuje dwie ręce splecione, żydowską i polską, i gwiazdę Dawida i krzyż”. Sprawa antysemityzmu wypływa ponownie przy okazji opisu targu. Piotr Fronczewski komentuje: „Czasem znienacka wpadają polskie nacjonalistyczne bojówki i zaczynają przewracać i bić”. Muzyka na chwilę zmienia nastrój na minorowy. Widzimy współczesne zbliżenia pieczywa, czosnku i marchewek, na które pada cień. To wszystko. Po chwili powraca skoczna, wesoła muzyka i opowieść toczy się dalej.

32 W oryginale książki Hilberga pojawia się słowo by-stander w polskim tłumaczeniu oddane jako „świadek”. Dokonujące się tu przesunięcie akcentu, a wręcz zmiana znaczenia, zasługuje na osobne omówienie.

33 „Powinni byli uratować się ci Żydzi, którzy z getta zdołali się wydostać, którzy otrzymali aryjskie dokumenty, którzy mieli gdzie mieszkać. Oni mogli i powinni spokojnie po tym żyć, o tyle spokojnie, o ile żyli Polacy-nie-Żydzi, Polacy-chrześcijanie. [...] Dlaczego ci Polacy, którzy zobaczywszy Żyda, nie mając zamiaru go zadenuncjować albo szantażować, nie umieli tego faktu zamilczeć? [...] Przecież niczego się już nie pragnie od nich jak tego milczenia, jak tego nieszeptania na ucho drugim, również przychylnie ustosunkowanym do Żydów, którzy dalej szeptali, aż wyszeptano o tym w gestapo. [...] Gdyby byli absolutnie bierni, uratowaliby się prawie wszyscy uciekinierzy z getta. [...] Przecież żaden Niemiec nie odróżniał z początku Żyda od Polaka-Słowianina" [(Maria Nowakowska), Moja walka o życie, czyli wspomnienia Żydówki warszawskiej, Archiwum ŻıH, pam. 142 - cyt. za: Żbikowski: 2004: 182-183]. 
śmiertelnie niebezpieczne. Nie powstrzymywano się od ich demaskowania. Powszechnymi praktykami były szantaże, kradzieże, bezinteresowne odprowadzanie na polski lub niemiecki posterunek, także zabójstwa czy polowania z nagonką - te ostatnie na prowincji34. Ci, którzy zdecydowali się ukrywać Żydów, ukrywali ich w pierwszej kolejności przed sąsiadami. Odwaga „Sprawiedliwych” polegała przede wszystkim na sprzeciwie wobec norm obowiązujących we własnej - polskiej, katolickiej - społeczności. Przeważające postawy polskiej większości przyczyniły się do realizacji „ostatecznego rozwiązania”. Społeczność, która nie pozwoliła Żydom ukryć się po aryjskiej stronie i jednocześnie masowo czerpała materialne korzyści z ich wymordowania, nie może określać się mianem „świadków” ani tym bardziej: „strażników pamięci”.

Po drugie, postawy wobec Żydów w czasie wojny nie wzięły się znikąd. Odzwierciedlały kod polskiej kultury, ukształtowany znacznie wcześniej. Unicestwienie Żydów jako potencjalność zawarte było w strukturze antysemityzmu - zarówno przednowoczesnego [Tokarska-Bakir 2004: 66-67], jak i nowoczesnego. Za antysemityzmem stała moralna sankcja większościowej religii dominującej. Likwidacyjne fantazmaty zostały w Polsce wyartykułowane jeszcze przed wojną i przygotowały wyobraźnię społeczną na to, co miało nastąpić w latach czterdziestych [Janion 2000: 144-145]. Wiedziały o nich nawet dzieci. Krytykując koncepcję triady „sprawcy - ofiary - świadkowie”, Elżbieta Janicka opisywała gruntowne wprowadzenie i zaangażowanie rzekomych „świadków” Zagłady w powołaną przez dyskurs antysemicki „kwestię żydowską” ${ }^{55}$. „W odniesieniu do tej sytuacji trzecie ogniwo triady Hilberga nie funkcjonuje. [...] Proponowałabym tu termin «obserwacja uczestnicząca wtajemniczona», bo sama «obserwacja uczestnicząca» to za mało. Byłaby ona dokonywana w trybie myśli, mowy, uczynku i zaniedbania. W tej kategorii - wydaje mi się - jest miejsce na mnogość i zniuansowanie przejawów. I być może otwiera ona także furtkę do zrozumienia, że tutaj chodziło o większość - zdecydowaną, a nade wszystko decydującą: o tym, że «cała Polska była gettem»" [Janicka 2008: 238] ${ }^{36}$. W świetle dostępnej wiedzy historycznej oraz obserwacji większościowych postaw transmitowanych do dzisiaj w polskim społeczeństwie, kategoria „świadka” traci sens w odniesieniu do polskiej społeczności, tak jak ją przedstawia Dylewska.

Po trzecie, antysemicka przemoc - znowu: polska - była jedną z przyczyn masowej ucieczki Żydów z Polski tuż po wojnie ${ }^{37}$. Natomiast w roku 1968, w majestacie państwa i prawa, spowodowała wypędzenie kilkunastu tysięcy obywateli, których w tym celu wystarczyło zakwalifikować jako „Żydów”. Po-lin całkowicie abstrahuje od faktu, że to nie Zagłada, lecz jej przedłużenie - przez Polaków - położyło kres żydowskiej obecności

\footnotetext{
$34 \mathrm{Na}$ temat cichego porozumienia między Niemcami jako „redaktorem odpowiedzialnym” za Zagładę a polską społecznością, przykładającą do niej rękę i korzystającą z jej skutków zob. Perechodnik 2004; Żukowski 2010.

35 Adorno kwalifikuje kategorię „kwestia żydowski” (die Judenfrage) jako znak antysemickiej postawy i świadomości [Adorno 2010: $137 \mathrm{nn}$.].

36 Ostatnie słowa to fragment wypowiedzi Jana Karskiego: „Nie było tak trudno wyjść i wrócić. Trudno było Żydom z innych powodów. [...] Niech będzie, że Żyd uciekł z getta, no i co teraz? [...] Cała Warszawa była gettem. Cała Polska była gettem" [Karski 1999: 15].

37 Joanna Tokarska-Bakir używa w odniesieniu do tego zjawiska kategorii czystki etnicznej [Tokarska-Bakir 2011: 803].
} 
w Polsce. Seria powojennych pogromów, akcja wagonowa i wcale nieodosobnione zabójstwa osób, które próbowały wrócić do swoich domów i wyjaśnić los bliskich, wynikały z tego, że Żydów w Polsce nie chciano. Zagładę powszechnie aprobowano [Libionka 2006]. Podobnie jak jej materialne skutki. Ludzie, którzy przejęli własność żydowską, nie chcieli niczego zwracać i nie pragnęli powrotu dawnych właścicieli i sąsiadów. Również z tego powodu trudno nazywać mieszkańców pożydowskich domów „świadkami” i kreować ich na „strażników pamięci”.

Przemilczenia są kolejnym czynnikiem, który sprawia, że Po-lin, zamiast opowieścią o polskich Żydach, jest autoreprezentacją grupy dominującej, jakoby nostalgicznie zapatrzonej w ślady po dawnych sąsiadach. Mamy do czynienia z perpetuum mobile: melancholijna poetyka produkuje niewinnych „świadków” i „spadkobierców”, niewinni „świadkowie” i „spadkobiercy” - melancholijną poetykę. Poruszamy się bez końca w błędnym kole wyobrażeń o samych sobie bez potrzeby konfrontacji z rzeczywistością.

\section{Obróbka Zagtady}

\section{a) poza historią (mityzacja)}

Jolanta Dylewska konsekwentnie pomija Shoah. Jak zresztą każdy społeczny konkret. Film zaczyna się od wyjaśnienia: „Żydzi, uciekając z Niemiec przed pogromami i zarazą, przybyli do Polski. Spotkali się z gościnnością i życzliwym przyjęciem. Powiedzieli po hebrajsku PO-LIN - tu zamieszkamy - nadając w ten sposób żydowską nazwę Polsce. Tak głosi trzynastowieczna legenda”. Po zmianie planszy czytamy: „W chwili wybuchu drugiej wojny światowej żyło w Polsce 3,5 miliona Żydów, co stanowiło 10\% mieszkańców Rzeczpospolitej".

Historia „nagłego zniknięcia” Żydów - jak wyraziła się recenzentka filmu w dzienniku „Rzeczpospolita” [Hollender 2008: A20] - przedstawiona zostaje w szczególnej perspektywie. Oto w XIII w. Żydzi uciekają przed okrutną Europą i znajdują w Polsce gościnę. Rozpoznajemy ten obraz i siebie w tym obrazie. To znana i lubiana figura Paradisus Judeorum $^{38}$. Nic jej nie zakłóca, bo też nie dowiadujemy się niczego o siedemsetletnim życiu Żydów w Polsce. Użycie paternalistycznej formuły gościny ${ }^{39}$ - skądinąd zupełnie ahistorycznej - mogłoby sugerować, że coś tu nie gra. Jednakże w polskim dyskursie więk-

38 W autoreprezentacji większościowej figura Paradisus Judeorum pełni istotne funkcje, o czym można się zorientować, odwiedzając stronę internetową polskiej fundacji o tej nazwie. Psycholog-psychoterapeuta interpretuje ją w następujący sposób: „Polacy pragną widzieć swój kraj jako oazę tolerancji na przestrzeni wieków - kraj bez stosów [Fakt, że byt to kraj ze znacząco mniejszą ilością stosów nie wystarcza - ma być «bez stosów», tak jak uczono nas w szkole]. Połączenie nazwy z antysemicką treścią fundacyjnej strony internetowej stanowi jasny przekaz: Polska była rajem dla niewdzięcznych Żydów, a Polacy pełnili w nim role aniołów" [Biedka 2008].

39 Formuła "gościny” jest elementem nacjonalistycznego i w gruncie rzeczy ksenofobicznego dyskursu, którego założeniem jest uznanie państwa za własność dominującej grupy etnicznej. Motyw ten analizowała Katarzyna Chmielewska na przykładzie gimnazjalnych podręczników do wiedzy o społeczeństwie w raporcie z programu „Szkoła otwartości” zrealizowanego przez „Otwartą Rzeczpospolitą” - Stowarzyszenie przeciw Antysemityzmowi i Ksenofobii [Chmielewska 2004]. Stowo "gościna” w odniesieniu do stosunków polsko-żydowskich pojawia się także u powściągliwych skądinąd historyków w funkcji ironicznej: „Gorzej jeszcze, na listę «ofiarnych ratujących» [...] trafit również niejaki Michał K., który [...] miał przechowywać dziesięcioro Żydów. Michał K. rzeczywiście przechowywał troje Żydów, ale zatłukł ich siekierą późną jesienią 1944 r., kiedy skończyły im się pieniądze na opłacanie gościny” [Grabowski 2011: 55]. 
szościowym występuje ona w pakiecie z toposem Paradisus Judeorum i - jako taka - nie uchodzi za podejrzaną. Logika filmowej narracji każe zaś wierzyć, że obraz wyłaniający się z archiwalnych zdjęć dokumentalnych i wspomnień „świadków” odzwierciedla wielowiekowe harmonijne wspótistnienie gości i gospodarzy. Europa - której przemoc od początku objawia się pod postacią Niemiec - niszczy jednak sielankę.

\section{b) daleko stąd (eksterytorializacja)}

Plansze wprowadzające w polsko-żydowską historię zawierają ukryte założenia konstytutywne dla opowieści Dylewskiej. Przemoc wobec Żydów w Polsce ma charakter zewnętrzny. Polska i Polacy nie mają z nią nic wspólnego i w tym sensie nie należą do Europy. Są wyjątkiem od antysemickiej normy uosabianej przez Niemcy, wrogie Żydom od czasów wypraw krzyżowych. Wolno zatem wnioskować, że to, co wydarzyło się po 1939 r. było ingerencją w świat dobrosąsiedzkiego współżycia. Obcą przemocą, która nie wpisywała się w miejscowe realia.

To jednak jeszcze za mało. W tekście odczytywanym przez Piotra Fronczewskiego pojawia się legenda o rabbim Elimelechu. Brzmi ona tak: „W latach sześćdziesiątych XVIII w. młody Elimelech z bratem Zusją wędrowali z miasta do miasta jako żebracy, by ówczesnym zwyczajem chasydów uczyć się pokory. Przybyli do niewielkiego miasteczka. Chociaż byli głodni, nie mogli jeść. Chociaż byli wyczerpani, nie mogli spać. Ogarnęło ich uczucie niewypowiedzianego lęku. Ogarnął ich najgłębszy smutek. W środku nocy opuścili miasto i już nigdy do niego nie wrócili. To miasto nazywało się [dramatyczne zawieszenie głosu] Auschwitz".

Żydów deportowano ze wszystkich sztetli, które oglądamy w Po-lin, w niektórych przypadkach zabijano na miejscu. Polskie otoczenie dopuszczało się przy tym rzeczy straszliwych, o których wiadomo ze świadectw ocalonych, a także ze wspomnień niektórych Polaków. Jolanta Dylewska tymczasem sprowadza Zagładę do jednego symbolu - Auschwitz. Eksterminacja zostaje tym samym ograniczona terytorialnie. Skoro święci mężowie nie czuli lęku w innych miejscach, mogli jeść i spać, nie wydarzyło się tam, widać, nic aż tak niepokojącego. Horrendum ogranicza się do miejsca ściśle niemieckiego w sensie kulturowym - patrz: niemiecko brzmiąca nazwa. Dodatkowo miejsce to jest geograficznie oddzielone od obszarów, o których opowiada film. Odium w najmniejszym stopniu nie dotyczy Polaków. W tak skonstruowanej opowieści zarezerwowano dla nich przecież rolę „świadków” - kogoś fizycznie i symbolicznie oddzielonego od zbrodni. Widzowie i dzisiejsi mieszkańcy pożydowskich miasteczek mogą spać spokojnie.

\section{c) „nagłe zniknięcie” na mocy tego, co komu pisane (predestynacja)}

Historia o Elimelechu i Zusji jest częścią większej całości. Dylewska wpisała swoją opowieść w rytm natury (dnia, tygodnia, pór roku) i w naturalny cykl ludzkiego życia. Narracja 
o sztetlach - po wprowadzających wspomnieniach Polaków o żydowskich przyjaciołach i sąsiadach - zaczyna się wraz z początkiem dnia. Miasteczka budzą się do życia. Obserwujemy ich codzienność w wielu przejawach. Nadchodzi koniec tygodnia, szabat. Praca ustaje. Rytm roku to rytm świąt - Chanuka, Pesach, Rosz ha-Szana i Jom Kipur. Temat zmierzchu, zimy, śmierci, cmentarzy i życia wiecznego domyka opowieść.

Zwiastuny Zagłady pojawiają się jednak wcześniej. Po raz pierwszy w opowieści o „otoczonym aurą świętości” Mojsze Fuksmanie, „żarliwym wyznawcy cadyka z Lubawicz”, do którego przychodzą po błogosławieństwo „i Żydzi, i prawosławni, i katolicy”. Opowieść kończy się zdaniem: „Jeszcze dziesięć lat i dziesięć miesięcy”. W tle słychać odgłos porywistego wiatru. Motyw powraca później trzykrotnie. Memento mori zostanie powtórzone w identycznym kształcie przy okazji wspomnienia o odmieńcach. Wreszcie, tuż przed częścią o chasydach, w zakończeniu części poświęconej świętom, w materiale z lat trzydziestych widzimy dzieci idące gęsiego jedno za drugim. Lektor mówi o ich przyszłych losach. Wymienia imiona. I kończy: „Jeszcze dziesięć lat mają przed sobą”.

Trzykrotnie powtórzona zapowiedź katastrofy sugeruje, że nad ludźmi z archiwalnych zdjęć ciąży wyrok losu. Dźwięk wiatru - rodem z gotyckiej poetyki niesamowitości i grozy - sprawia, że widzowie mimowolnie odczuwają chłód. Jednocześnie zaś umieszcza Zagładę w kręgu znaczeń powiązanych z naturą: z klęskami żywiołowymi w rodzaju trąby powietrznej albo z zimą jako czasem śmierci. Shoah staje w jednym rzędzie ze zdarzeniami, których przyczyny leżą poza ludzkim światem, w sferze działania sił, na które nie mają wpływu ani jednostki, ani społeczności.

\section{d) w porządku boskim (trywializacja)}

Dylewska dodaje do tego jeszcze jeden kontekst - religijny, a konkretnie chasydzki ${ }^{40}$. Śmierć, także Zagłada, wpisuje się w boski porządek, a tym samym jeszcze bardziej oddala od społecznego konkretu. W opowieści o rabbim Elimelechu oba kręgi znaczeń nakładają się na siebie. Słyszymy wycie wiatru, widzimy pieńki wykarczowanych krzaków na zapuszczonym kirkucie, kamera skupia się na popiele po zgasłym ognisku. Elimelech i Zusja przeczuwają Shoah na sposób metafizyczny - jako eksces nadprzyrodzonego zła zapisany w boskich planach.

Następna sekwencja opowiada o cmentarzach. Żydowskie rozumienie śmierci ma streszczać się w takich oto słowach: „Na wieść o czyjejś śmierci przywołują specjalne błogosławieństwo: «Błogosławiony niechaj będzie sędzia sprawiedliwy!». O zmarłym mówią: «przebywa w świecie prawdy». Cmentarz nazywają «domem życia», «dobrym miejscem», i uważają za miejsce święte. Obok ludzi grzebią na nim stare podarte księgi i karty ze świętych ksiąg”. Lektor mówi o Ester Chai, która rozmawiała ze zmarłymi. $\mathrm{Na}$

40 Przypowieść o Elimelechu została umieszczona wewnątrz opowieści o wielkich cadykach i cmentarzach. Świat chasydów to świat obcowania z Bogiem i zmarłymi. Święci cadykowie są pośrednikami: znajdują się w połowie drogi między Bogiem a ludźmi. Śmierć powiększa tylko ich moc, jako że zbliża ich do nieba, ale jednocześnie nie oddala zanadto od ludzi. Oglądamy ohele budowane nad ich grobami i pozostawiane tam kartki z prośbami i intencjami. Głos lektora zapewnia, że "nikt nie odchodził od cadyka niewysłuchany”. 
ekranie pojawiają się współczesne ujęcia żydowskich cmentarzy utrzymane w wysmakowanym i malowniczym stylu - patrz „fotografia ojczysta”. Słychać wycie wiatru.

Cmentarze, które oglądamy, odsyłają do dwóch porządków. Po pierwsze, mówią o naturalnej śmierci - tych, którzy umarli przed Zagładą. Po drugie, są znakami eksterminacji jako ślady po społeczności, której już nie ma. U Dylewskiej różnica ta zaciera się. Skoro przypowieść o Elimelechu wpisuje ludobójstwo w porządek nadprzyrodzony, to religijne rozumienie śmierci rozszerza się także na Shoah. W kontekście komór gazowych niezmiernie trudno zgodzić się na przywoływanie słów „Błogosławiony niech będzie sędzia sprawiedliwy!”. Nie sposób też przyjąć perspektywy, w której śmierć byłaby tylko bramą prowadzącą do nowego, lepszego życia albo etapem w następstwie pokoleń. Jest to tym bardziej nie do przyjęcia, jeśli nad narracją panuje polski głos - głos grupy dominującej, która nie chce mówić o własnym uwikłaniu w eksterminację.

\section{e) wyrwanie $z$ kontekstu (uniwersalizacja)}

Religijny i nadprzyrodzony kontekst pozwala ostatecznie wyabstrahować Zagładę ze społecznych konkretów. Obraz melancholijnie pięknych i malowniczo opuszczonych cmentarzy przenosi Shoah w dziedzinę uniwersalnego przemijania. Kropkę nad „i” stawia jeden z polskich „świadków”: „Tak wygląda, jakbym się przespał, wstał, i już nie ma nic. Tamte lata, tak się zdaje, jakby to było rok temu, a to już jest... Wszystko przemija strasznie i bezpowrotnie. [Kamera filmuje spracowaną, niespokojnie poruszającą się dłoń.] Wszystko bezpowrotnie już”. Trudno zaprzeczyć. Jednakże polscy Żydzi w Polsce „przeminęli” inaczej niż „wszystko przemija”. Różnica dzieląca grupę dominującą - nawet jeśli uznać ją tylko za świadków - od eksterminowanych jest na tyle radykalna, że żydowskich śmierci nie sposób sprowadzić do wspólnego mianownika uniwersalnego przemijania. Zapomnienie o tej różnicy jest jednak konieczne, żeby polska społeczność mogła nie zadawać pytań dotyczących jej własnych zachowań. Groźba dochodzenia, co właściwie stało się na granicy getta i aryjskiej strony oraz co z tego dzisiaj wynika dla "nas”, zostaje oddalona. W zamian Po-lin oferuje fałszywą i pozorną konfrontację. Z tajemnicą.

O tym, jak działa mechanizm uniwersalizacji, można przekonać się na przykładzie historii o Racheli Szemesz. Jedna z Polek opowiada: „Pracowałam za okupacji na poczcie... w Kolbuszowej. Pamiętam, jak szłam raz do pracy i taką... taką upośledzoną Żydówkę prowadził Twardoń, to znaczy ten starosta ówczesny, kolbuszowski. [...] I po prostu czuŁam, że prowadzi ją na śmierć". Słowem, kanoniczna scena z rytuału wyłapywania Żydów i wydawania ich na stracenie - w biały dzień, na widoku publicznym ${ }^{41}$. Rozmówczyni Dylewskiej jest bardzo poruszona. Widać, że dotyka najboleśniejszych wspomnień. Ale jej opowieść urywa się. Przechodzimy do filmów z lat trzydziestych. Otchłanny głos Piotra Fronczewskiego pyta: „Czy to będzie Rachela Szemesz? Rachela Słońce?”. I kończy jednym z trzech pojawiających się w Po-lin memento mori: „Jeszcze stoi tutaj”. Zbliżeniu wycinka

41 W pracy na ten temat napotykamy na określenia: rytuał, schemat, scenariusz, rutyna zbrodni [Grabowski 2011]. 
archiwalnych zdjęć towarzyszy odgłos wiatru. Dylewska nie pyta, kim był Twardoń. Polsko brzmiące nazwisko oprawcy nie budzi jej podejrzeń, ani nie wnosi żadnej poprawki do filmowej narracji. Wątek, który musiałby rozbić harmonijną opowieść, natychmiast gubi się, bo zdarzenie zostało pokazane w perspektywie losu, a nie historii ludzkich działań ${ }^{42}$.

\section{f) „Śnią nam się uśmiechnięci”: przyjaźń do śmierci, przyjaźń po śmierci}

W części poświęconej śmierci Dylewska ponownie stawia polskich „świadków” w bezpośredniej bliskości ofiar: z jednej strony potwierdzając ich rolę jako „stróżów pamięci”, z drugiej przedstawiając jako tych, nad którymi czuwają żydowscy umarli. Opis święta Jom Kipur kończy się obrazem rabina błogosławiącego kobiety i mężczyzn. „A oni - prawi lektor - pomni, że właśnie w niebie otwarto księgę życia i księgę śmierci, żałują za grzechy, proszą Najwyższego, żeby wybaczył im słabości i upadki, by zapisał ich do księgi życia na nowy, dobry rok”. Znikają zdjęcia archiwalne, kamera wpatruje się we współcześnie filmowane okno. W szybie odbijają się drzewa. Cięcie. Z archiwalnych taśm spoglądają ludzie, jakby patrzyli w pokazywane przed chwilą okno i czekali na coś. Wraz z ostatnią frazą o księdze życia pojawia się macewa z motywem otwartej księgi. Kamera najeżdża na nią, widać rysy na kamieniu i palec ręki, która trzyma księgę. W następnym ujęciu pojawia się Polka, która wspomina żydowską przyjaciółkę, po niej następni „świadkowie” w podobnej roli. Jeden z nich mówi o przyjacielu, który śnił mu się „uśmiechnięty taki, zadowolony”. „No mówię, może on jest uśmiechnięty” - kończy. Montowane na przemian twarze „świadków” i zdjęcia archiwalne sprawiają wrażenie wywoływania z pamięci żywych obrazów. Polka wspomina ubogą żydowską dziewczynkę. Uboga żydowska dziewczynka - choć najprawdopodobniej inna - macha do widzów z archiwalnego filmu. Podobnie jak jeden z wywołanych z pamięci przyjaciół - zdolny skrzypek. Księgą życia, o którą modlili się Żydzi w Jom Kipur, okazują się polscy „świadkowie”.

Według występujących w Po-lin „świadków” ofiary Shoah śnią im się w optymistycznej aurze, co Jolanta Dylewska wzmacnia konstrukcją filmu. Sny o umarłych rzadko bywają pogodne. Oto zatem Polacy zasłużyli na nie lada przywilej. Po pierwsze dlatego, że polskich i żydowskich sąsiadów łączyły tak ciepłe stosunki, że „nagłe zniknięcie” Żydów nic tutaj nie zmieniło. Skoro „świadkowie” byli przyjaciółmi - a do tego nadal dochowują przyjaźni jako „strażnicy pamięci” - umarli okazują im wdzięczność. Po drugie, w religijnym obrazie świata - wpisanym w opowieść o chasydach i prezentowanym jako żydowski punkt widzenia - śmierć nie jest wydarzeniem aż tak strasznym. Skoro zmarŁy „przebywa w świecie prawdy”, a Żydzi nazywają cmentarz „domem życia” i „dobrym miejscem", Zagłada daje się ogarnąć i można się z nią pogodzić. Stąd przypuszczenie dotyczące zamordowanego przyjaciela, że „może on jest uśmiechnięty”. Po tamtej stronie.

42 Dylewska konsekwentnie nie podejmuje wątku polskiej przemocy antysemickiej jako fenomenu czy wręcz rytuału społecznego, obudowanego licznymi racjonalizacjami i usprawiedliwieniami. Fragment o Twardoniu nie jest w żaden sposób powiązany z napomknieniem o przedwojennym antysemityzmie. Dylewska nie pyta, czy istnieje jakiś związek między stosunkami polsko-żydowskimi w epoce, o której opowiada, a późniejszą śmiercią Racheli Szemesz. W zamian demonstruje nam herb Kolbuszowej. 
Pogląd ten wyraża wprost inny „świadek”: „Wiem, że te dusze wiedzą o nas, widzą nas, pamiętają o nas. I nadal żyją, tylko już w lepszym świecie”. „Lepszy świat” rozgrzesza ten świat. W obliczu wieczności na dalszy plan usuwa się wszystko, co wydarzyło się tutaj: za życia i tuż przed śmiercią ofiar, a także po ich śmierci.

Wypowiedź ta jest podsumowaniem części o chasydzkich świętych, którzy opieką obejmują teraz polską społeczność. W perspektywie Po-lin, a więc w granicach narracji budowanej przez grupę dominującą, umarli Żydzi wystawiają polskim sąsiadom najlepsze świadectwo. Dlatego współczesne fotografie żydowskich cmentarzy mogą - a nawet muszą - być tak wysmakowane i piękne, prześwietlone ciepłym światłem i nienagannie skomponowane ${ }^{43}$. Ich tematem jest bowiem obraz grupy dominującej, a nie żydowska tragedia. Jan Bułhak zalecał fotografowanie przydrożnych krzyży: „I tak oto będzie nas uczyła fotografia ojczysta zaczynać od rzeczy materialnych, plastycznie uchwytnych i stopniowo sięgać w głąb, i odnajdywać duszę ziemi i duszę człowieka” [Bułhak b.d. (1939): 28]. U Jolanty Dylewskiej możemy zobaczyć macewy wrośnięte w drzewa, uderzająco podobne do wrośniętych w drzewa krzyży w albumie Polesie Krzysztofa Hejkego [Hejke 2009: 162-163]. Otrzymujemy obraz polskiej ziemi przygarniającej żydowskich umarłych, a więc obraz nas samych - takich, jakimi chcielibyśmy się widzieć ${ }^{44}$.

\section{8. Żydzi jako mityczny „Żyd”}

\section{a) zesłanie do rezerwatu (separacja i folkloryzacja)}

Kim są Żydzi, których tak dobrze wspominają Polacy? W Po-lin budowanie wizerunku Żydów zaczyna się od muzyki. Kompozytor Michał Lorenc nawiązuje do motywów, które są kulturowo rozpoznawalnymi znakami tradycyjnej „żydowskości”: klezmerskich skrzypiec i cymbałów. Muzyka w Po-lin jest ilustracyjna i emocjonalna. Podpowiada nastroje odbiorcy i sprawia, że odbiór afirmujący staje się łatwiejszy od krytycznego. Ścieżka dźwiękowa umieszcza obrazy filmowe w przestrzeni folkloru traktowanego jako ikona tożsamości. „Żydowskość” zostaje tym samym zamknięta w zarezerwowanym dla niej polu odmienności kulturowej. Oswajanie łączy się z zakreślaniem osobnego miejsca i ustanowieniem granicy między tym, co polskie, a tym, co żydowskie. Uznanie odmienności idzie w parze $z$ oddzieleniem.

Zasadniczym rysem obrazu tworzonego w Po-lin jest folkloryzacja tego, co żydowskie. Folklor - ściśle powiązany z religią - jest podstawą rozumienia świata, reguł społecznych, a nade wszystko tożsamości. Staje się rodzajem niezmiennej esencji. Społeczność

43 W Po-lin pojawia się niepokojący obraz ohelu cadyka stojącego na czymś w rodzaju placu manewrowo-parkingowego. Wprawne oko dostrzeże w tym klepisku miejsce po żydowskim cmentarzu, a raczej żydowski cmentarz (bo groby pozostały, gdzie były), tyle że bez oznak zewnętrznych. Oko nieuprzedzone - czy umiejętnie znieczulone nie zrozumie, lub wręcz nie zarejestruje, tego widoku. Anestezjologicznej kategorii znieczulenia używamy nie bez kozery. W pracy o budynkach dawnych synagog Wojciech Wilczyk wykazał, że na gruncie polskiej kultury i historii kategoria niewinnego oka jest nieporozumieniem [Wilczyk 2009].

44 Wyobrażenie to pozwala abstrahować od społecznego zjawiska, jakim była powojenna dewastacja żydowskich cmentarzy idąca w parze z pomysłową utylizacją kradzionych macew - por. wystawa Łukasza Baksika Macewy codziennego użytku (kuratorka Ewa Toniak, konsultacja merytoryczna Joanna Tokarska-Bakir) w Centrum Sztuki Współczesnej Zamek Ujazdowski, Warszawa 2010. 
żydowska zostaje tym samym postawiona poza historią. Jej życie obraca się wokół religii i tradycyjnych zatrudnień, które kierują uwagę do wnętrza etnicznej i religijnej wspólnoty. Świat handlu, rzemiosła i usług nie przekracza właściwie granic mniejszościowej subkultury sztetli. Żydzi tworzą osobne uniwersum, które nie ma wiele wspólnego z resztą społeczeństwa i z przemianami, które w nim zachodzą.

Kosztem takiego zabiegu jest ucieczka od historycznego i socjologicznego konkretu. Obraz społeczności żydowskiej okazuje się jednolity i stereotypowy. Z pola widzenia umyka większość zjawisk związanych z modernizacją, a więc z funkcjonowaniem Żydów w obrębie nowoczesnego społeczeństwa. Jako członkowie homogenicznej i oddzielnej społeczności Żydzi nie stawiają polskiej większości żadnych żądań, ponieważ nie próbują wkraczać w obszar publiczny, gdzie nie dałoby się uniknąć pytania o równouprawnienie. Przeświadczenie o tolerancyjnym usposobieniu większości może pozostać nienaruszone, ponieważ nie pojawia się kwestia przyznania mniejszości równych praw w obrębie przestrzeni uznawanej przez dominujących za własną.

Tymczasem koniec XIX w. to narodziny żydowskich partii politycznych i nowych ruchów emancypacyjnych. Rewolucja 1905 r., rewolucja październikowa i rok 1920 wstrząsają starym światem i społecznymi wyobrażeniami. Zabójstwo Narutowicza i śmierć Piłsudskiego dotyczą Żydów i innych mniejszości narodowych II Rzeczypospolitej w szczególny sposób. Lata trzydzieste to koniec sztetli w ich tradycyjnej formie rodem ze społeczeństwa stanowego. Nowoczesny rynek i państwo tworzą przestrzeń, w której podmioty gospodarcze i obywatele są przynajmniej formalnie równi. Rodzą się w związku z tym aspiracje, które sięgają poza granice tradycyjnych wspólnot. Tu właśnie lokują się sprawy, o których nie chce mówić Dylewska. W latach dwudziestych i trzydziestych antysemickie akty przemocy były rzeczą powszednią i przybierały na sile. Państwo polskie spychało Żydów na pozycję obywateli co najmniej drugiej kategorii. Coraz bardziej jawnymi metodami próbowało usunąć ich z polityki, gospodarki i kultury. W powszechnym przekonaniu pojawienie się Żydów w jakimkolwiek miejscu życia publicznego uchodziło za tak zwaną nadreprezentację. Ukrytą stawką do ugrania podczas wybuchających w związku z tym konfliktów był kształt społeczeństwa, jego świadomość i tożsamość jako całości. Żydzi - coraz liczniej - nie widzieli powodu, by nie uczestniczyć we wspólnej przestrzeni na równych prawach i robili to jako przedstawiciele wolnych zawodów, działacze polityczni i członkowie partii, robotnicy, ludzie nauki, kultury czy sportu ${ }^{45}$.

Dylewska decyduje się nie widzieć obszaru, w którym dochodzi do faktycznego spotkania Polaków i polskich Żydów, i w którym kultura polska ujawnia swój stosunek do żydowskich współobywateli. Reżyserka tworzy obraz, który sankcjonuje granice wyznaczane mniejszości przez dominującą większość: Żydzi pozostają malowniczymi mieszkańcami „egzotycznego świata” i nie próbują pojawiać się w miejscach zarezerwowanych przez

450 partiach politycznych mówi się tylko raz, przy okazji żydowskich instytucji samorządowych. We fragmencie o KaŁuszynie pojawiają się komuniści jako „młodzi odstępcy od wiary”, którzy „raz w miesiącu zdążają pod warszawski most, gdzie chudy towarzysz Eidele z Warszawy czyta im broszurę ze streszczeniem Kapitału Marksa”. Narracja konsekwentnie wraca do religii i folkloru jako wątku konstytuującego obraz Żydów. 
Polaków dla Polaków. Dzieje się tak na przekór materiałom archiwalnym, gdzie nowoczesność daje o sobie wyraźnie znać. Świadczą o niej już sami autorzy zdjęć, czyli emigranci. Ludzie ci wyjeżdżali, szukając awansu społecznego, który w Polsce nie był możliwy z powodu antysemityzmu ${ }^{46}$. Reakcje mieszkańców sztetli także świadczą o ich nowych dążeniach: cieszą się z dobrobytu przyjeżdżających, ze zdziwieniem, ale i podziwem patrzą na ich modne stroje, sami naśladują ich sposób życia. Na zdjęciach widać różnicę między pokoleniem dziadków (tradycyjne stroje, brodaci mężczyźni, kobiety w perukach) a ich dziećmi i wnukami aspirującymi wyraźnie do nowych wzorów kultury, a co za tym idzie - do równości, którą obiecywała nowoczesność.

\section{b) „sympatyczny” rewers antysemickiej kliszy}

Zamknięcie Żydów w wydzielonej dla nich przestrzeni to nie wszystko. Polska pamięć kolektywna, którą Po-lin rejestruje i powiela, konstruuje szczególną charakterystykę „Żyda”. Obraz mniejszości jest przede wszystkim funkcją przekonań i praktyk grupy dominującej. Świadomość większości dysponuje nim tak, żeby nie mącił jej dobrego mniemania o sobie oraz w razie potrzeby uzasadniał i usprawiedliwiał przemoc. Dotyczy to - co oczywiste - stereotypów negatywnych, które w filmie prawie się nie pojawiają. Dotyczy jednak także wyobrażeń o tych cechach, które budzą podziw i które Dylewska traktuje jako przejawy życzliwej pamięci. Rozmówcy Dylewskiej cenią w Żydach z jednej strony pobożność i solidarność, z drugiej - bezgraniczną wyrozumiałość dla wszelkich przejawów dyskryminacji, z którymi spotykają się w kontaktach z Polakami.

„Tu, w ziemi Po-lin leżą ci, którzy odeszli w sławie. Admorzy ${ }^{47}$, nauczyciele i mistrzowie, podpory świata, święci i czyści, uczeni i bogobojni, książęta Tory. Wielu podążało i podąża za nimi" - w Po-lin często pojawiają się podobne charakterystyki. Oglądamy ludzi wychodzących z synagogi, starszych mężczyzn i chłopców w tradycyjnych strojach, z brodami i pejsami. Ujednolicony wizerunek „Żyda” zostaje dopełniony szeregiem objaśnień na temat żydowskiej religijności - najchętniej w wariancie chasydzkim.

Żydowska pobożność budzi podziw. Jest to jednak podziw szczególnego rodzaju. Rozmówcy Dylewskiej cenią w Żydach cechy, których ich zdaniem brakuje polskiej wspólnocie. Żydzi szanują swoją religię bardziej niż Polacy - czytaj: tak, jak Polacy powinni szanować własną. Stoi za tym przekonanie, że każda z grup musi dbać o spoistość. Konstruowany w ten sposób obraz „Żyda” umacnia polską społeczność w przekonaniu o zasadniczej

46 Emigracja ekonomiczna była wśród obywateli II Rzeczpospolitej częstym zjawiskiem, jednakże powody emigracji polskich Żydów nie sprowadzały się do przyczyn ekonomicznych. Zob. chociażby: Cała (oprac.) 2003. Charakterystyczna jest także wypowiedź wykluczonego, który uwewnętrznił punkt widzenia większości - w tym wypadku aryjskiej inteligencji polskiej - i po wygnaniu z Polski odkrywał inny świat: „Pozostając w kontaktach z licznymi profesorami uniwersytetów amerykańskich, z pewnym zdziwieniem stwierdziłem, że wielu z nich to Żydzi, którzy albo sami, albo ich rodzice urodzili się w Pińsku, Białymstoku, Rymanowie, Włocławku czy w innym mieście lub miasteczku polskim. Świadczy to o tym, jak duży, zupełnie nie wykorzystany potencjał intelektualny tkwił w maŁomiasteczkowych masach Żydów polskich" [Hurwic 1996: 171].

47 Admor - słowo związane z tradycją chasydzką, akronim hebrajskich słów: Adonejnu Morejnu We-Rabejnu ('Nasz pan, nasz nauczyciel i nasz mistrz'). Oznacza założyciela dynastii chasydzkiej i/lub wybitnego przywódcę duchowego, wielkiego cadyka. 
różnicy między dwoma światami oraz o konieczności konsolidowania polskiej, katolickiej wspólnoty przeciw obcym. Pobożność - rozumiana jako gwarancja szczelności granic grupy - pełni funkcję charakterystycznej cechy wyróżniającej. Jednocześnie żydowska pobożność ma charakter ambiwalentny. Z punktu widzenia polskiej większości pozostaje także jednym z elementów piętna oraz potencjalnym źródłem złowrogiej siły Żydów.

Na podobnej zasadzie działa przekonanie o żydowskiej solidarności. Wątek ten został rozwinięty w wypowiedzi jednego z rozmówców Dylewskiej, który najwyraźniej sięgnął do zasobu kolektywnych mitów dotyczących Żydów. „Był taki, proszę pana, co jeździł do stacji, po gości, no, do pociągu - opowiada. Męczyje go nazywali. Męczyje, bo on konie zajeżdżat. To oni się, proszę pani, zebrali w bóżnicy i kupili mu, panie, konia [cmoknięcie] ekstra! A on miesiąc pojeździł, bo im żreć nie dawał, i znowu zajeździł. Myśli pani, że go potępili?! Kupili mu drugiego! To on drugiego zajeździł! A u nas by dali? Za cholerę by nie dali! To jest taka robota! Była u nich solidarność międzyludzka!”. Na ekranie pojawiają się archiwalne zdjęcia dobrze wyglądających, brodatych Żydów, być może gminnej starszyzny. Domyślamy się, że ludzie, których widzimy na ekranie, koordynują grupową solidarność wśród Żydów.

Klisza, z którą mamy do czynienia, to klisza antysemicka. Sam przykład - absurdalny, przejaskrawiony i noszący wszelkie cechy potocznej wyobraźni - ma świadczyć o szczególnej cesze charakteryzującej Żydów: popierają się nawzajem, są między sobą solidarni aż do granic zdrowego rozsądku, a nawet wbrew niemu. Ich wewnątrzgrupowa solidarność gwarantuje dobrobyt i - w domyśle - jest podstawą siły Żydów w zetknięciu z zewnętrzem. W tego rodzaju rozumowaniu żydowska solidarność staje się argumentem za tym, że podobna solidarność przydałaby się także wśród Polaków. Brak polskiej solidarności, nad czym boleje rozmówca Dylewskiej, jest groźny, bo przyczynia się do porażki Polaków w starciach z Żydami. Ostatni człon rozumowania, będący dopełnieniem antysemickiej kliszy, nie pojawia się w filmie, ale jest oczywisty dla każdego kompetentnego użytkownika polszczyzny. Fantazmat żydowskiej solidarności funkcjonuje jako powód i usprawiedliwienie sprzymierzania się większości przeciwko Żydom. Najdziwniejsze wydaje się to, że Dylewska bierze tę wypowiedź za dobrą monetę, nie dodaje żadnego krytycznego komentarza. Mało tego, prostodusznie potwierdza ją obrazem zażywnych mężczyzn. Przeniesiony z dziedziny fikcji w obszar naoczności fantazmat zostaje zobiektywizowany: widz może się przekonać na własne oczy, że naprawdę było tak, jak mówi polski „świadek”.

Wytwarzany i akceptowany przez grupę dominującą „pozytywny” obraz „Żyda” - przedstawiony przez Dylewską jako życzliwa pamięć o zamordowanych - stanowi rewers, a więc część antysemickiej kliszy. Podziw nie jest tu afirmacją inności, lecz gotowym do użycia uzasadnieniem obrony, czyli de facto usprawiedliwieniem przemocy i wykluczenia Żydów jako obcych z przestrzeni zarezerwowanej dla Polaków. Ten sam obraz obezwładnia ich, izoluje i nie podsuwa żadnych wyobrażeń, które dawałyby nadzieję na zmianę statusu akceptowaną przez większość. Folklor, chałaty, brody i pejsy lokują „Żyda” 
w rezerwacie: oddzielają od współczesności oraz od realnego życia. Przenoszą w dziedzinę legendy, gdzie ujawnia się istota obcego - godnego może podziwu, ale jednocześnie groźnego dla większości. Żydów - pod zastraszająco anachroniczną postacią - odesłano w Po-lin do muzeum. W muzeum tym nie przechowuje się jednak pamięci o ich faktycznym życiu, lecz strzeże podszytych lękiem większościowych wyobrażeń o ich mocy oraz związanych z nią zagrożeniach.

\section{c) sakralizacja wykluczenia}

Dzięki przypisywanej Żydom świętości ich wizerunek wytworzony przez większość okazuje się nienaruszalny. W Po-lin komentarz przybiera często biblijny ton: mówi się o "mężczyznach bogobojnych, uczonych i prawych”; „kobietach cichych i skromnych, oddanych swoim rodzinom całym sercem” albo „kobietach skromnych, pobożnych i dzielny$\mathrm{ch}^{\text {"48 }}$. Każda próba analizy i krytyki okazuje się bezsilna wobec mitu i sacrum, dostojeństwa patriarchów i szacunku dla odwiecznego, patriarchalnego porządku. Tym bardziej nie sposób zarzucić czegokolwiek polskiej pamięci, która przechowuje dla potomnych tak wzniosły obraz. Uświęcenie wizerunku Żydów oznacza jednak także uświęcenie wszystkiego, co za nim stoi. Przypieczętowuje przekonania większości, podział ról i przestrzeni. Szacunek dla przechowywanego w pamięci sacrum nie daje się oddzielić od sakralizacji praktyk grupy dominującej, która w ten sposób umacnia swoją władzę nad mniejszością.

Faktycznej separacji obu społeczności towarzyszą pozorowane spotkania. W tej roli świetnie sprawdza się filosemityzm kulinarny. Rozmówcy Dylewskiej rozwodzą się o smaku żydowskich potraw i o tym, jak sami zaczęli je przygotowywać. W trybie komplementu podkreślają, że żydowskie specjały nigdy nie udawały im się tak, jak dawnym sąsiadkom-Żydówkom. Sentyment do czulentu albo kugla i sugestia dzielenia stołu mają być świadectwem przyjaźni. Przyjaźni, której - sądząc po pozostałych elementach charakterystyki - nie było. Znajomość potraw nie idzie bowiem w parze z wiedzą i pamięcią, która wykraczałaby poza oleodruk i zostawiała w dyskursie większości miejsce na żydowski głos. Zamiast niego powraca przeświadczenie o istotowej różnicy i odmienności.

Po-lin rozbudza melancholię, której przedmiotem są najbardziej stereotypowe wyobrażenia o Żydach. Wyobrażenia te stanowią pochodną wygodnego, bezproblemowego autowizerunku polskiej większości - obrazu własnego autorstwa, w którym może się ona rozpoznać i odnaleźć z poczuciem zadowolenia.

48 Dylewska dopełnia patriarchalny zestaw wyobrażeń o żydowskich kobietach sceną przedstawiającą śmiejące się młode dziewczyny. Słyszymy chichoty, tzw. dziewczęcy gwar oraz ćwierkanie ptaszków. Obok szacownych matek mamy więc i obiekty seksualne - pełne uroku „Sulamity”. Oba elementy łączą się bez najmniejszego zgrzytu, bo $\mathrm{w}$ istocie są częściami tego samego stereotypu. 


\section{9. „Dobry Żyd” i jego zastosowania}

\section{a) „Żyd" ci wszystko wybaczy}

W polskich wspomnieniach Żydzi okazują się uprzedzająco grzeczni, usłużni i życzliwi dla Polaków. Przyjrzyjmy się na początek takiej oto relacji kulturalnej pani ze Słonima: „Trzydziesty szósty rok, trzydziesty siódmy, zaczął się ruch wśród Polaków, że trzeba troszkę odżydzić te kresowe miasta pod względem handlowym. I rzeczywiście w Słonimie się zrobił wielki ruch. Żydów to bardzo zaniepokoiło. Państwo Kosmowscy przyjechali z kapitałem, z porządnym towarem, założyli wielki sklep manufakturowy. Ja wiem, że moi rodzice przedtem kupowali w takiej półhurtowni pana Meszela. Dostawaliśmy jakieś tam upusty. Mamusia chciała popierać handel polski. Więc mamusia, z prawdziwym żalem i takim zawstydzeniem, poszła i powiedziała: «Pani Meszelowa, ja muszę przejść». To ona płakała rzewnymi łzami, ale powiedziała, że ona rozumie”.

Nie ulega wątpliwości, że mamy do czynienia z opisem aktu przemocy antysemickiej. Podjęta przez Polaków akcja „Nie kupuj u Żyda!” była próbą wykluczenia grupy współobywateli z rynku tylko dlatego, że byli Żydami. Celem bojkotu ekonomicznego było pozbawienie Żydów środków do życia, a więc zniszczenie ekonomicznych podstaw ich bytowania. Dopowiedzmy: bez pracy i zarobków nie sposób żyć. Pozostają nędza, głód lub emigracja, na którą też trzeba mieć siły i środki. W Po-lin zdarzenie zostaje jednak opowiedziane językiem, w którym gubi się brutalność sytuacji. Kategorie stojące u podstaw antysemickiego światopoglądu wydają się wynikać z samej istoty rzeczy. Są oczywistością społeczną. Polacy to Polacy, Żydzi to Żydzi - ze zobowiązaniem do grupowej solidarności. Żydzi stanowią problem, „kwestię żydowską”. Nie można tego tolerować, więc coś z tym trzeba zrobić. Reguły postępowania dyktuje Polakom siła wyższa pod postacią imperatywu kategorycznego: skoro handel pozostaje „w żydowskim ręku”49, „trzeba” miasteczka „odżydzić”. Nie ma wyboru.

W tym miejscu kulturalnemu antysemicie przychodzi w sukurs polszczyzna ze swoim słowotwórczym potencjałem oraz zasobami zdrobnień. „Odżydzić” było „trzeba”. „Troszkę”. Nie dowiadujemy się jednak, ile, czy jak bardzo. Można wnioskować, że „troszkę” nie odnosi się tu do stopnia realnego ograniczenia bojkotu ekonomicznego, a więc nie opisuje rzeczywistości - w rzeczywistości przemoc szła na żywioł - lecz pełni funkcję eufemizmu. „I rzeczywiście w Słonimie się zrobił wielki ruch” - mówi kulturalna pani. „Wielki ruch”, by „troszkę odżydzić”? Żydzi w tej sytuacji „niepokoją się” - kolejny eufemizm - ale nie „troszkę”: „bardzo”. A może powinni byli „niepokoić się” jedynie „troszkę” - proporcjonalnie do rozmiarów planowanego przez Polaków „odżydzenia”? Połączenie przerażającego „odżydzić” z relatywizującym - pomniejszającym, bagatelizującym i wręcz infantylizującym - „troszkę” generuje komunikat, który pozwala sprawcy przemocy czuć się komfortowo tam, gdzie ofiarę przemocy ogarnia trwoga ${ }^{50}$.

\footnotetext{
49 Motyw „opanowania” małomiasteczkowego handlu przez Żydów pojawia się w Po-lin kilkakrotnie.

50 Podobną prawidłowością rządziło się przemówienie Władysława Gomułki na VI Kongresie Związków Zawodowych, w czerwcu 1967 r. Gomułka wyraźnie mówit, że nie wszyscy Żydzi mają powody do niepokoju. I dla mniejszości, i dla większości było zrozumiałe, że chodzi o wszystkich Żydów. Jednak z punktu widzenia samooceny Polaków formuła Gomułki zdecydowanie lepiej brzmiała niż otwarte postawienie sprawy.
} 
Siła wyższa pozostaje jednak siłą wyższą. „Odżydzanie” nie ma nic wspólnego z antysemityzmem. Oczywiście. Chodzi o patriotyzm - zrozumiały sam przez się - i o wymierną jakość towarów. Polska konkurencja jest w gruncie rzeczy bezkonkurencyjna. Sklep państwa Kosmowskich jest wielki, dysponuje kapitałem i „porządnym towarem”, co różni go od opisywanej z nutką pogardy „półhurtowni”, której właściciel dawał „jakieś tam upusty". Bojkot ekonomiczny - jak podpowiada antysemicki stereotyp - oznacza zatem koniec przysłowiowej „żydowskiej tandety”. W warstwie obrazów przechodzimy od nędznych zaułków ze zdjęć archiwalnych do eleganckiej ulicy handlowej. Na pierwszym planie grupa robotników zakłada na słupach kable telefoniczne. Widać witryny sklepów: z towarami łokciowymi H. Brańskiego oraz z winami i wódkami Wt. Szejkierca - Polaka, sądząc po imieniu.

W świecie polskiej pamięci nie ma języka, którym można opowiedzieć o prześladowaniu Żydów z zewnątrz antysemickiego stereotypu, z dystansem pozwalającym zobaczyć, co się naprawdę dzieje. W relacji pani ze Słonima problem nie polega na przemocy, ale na uczciwym i kulturalnym potraktowaniu żydowskich sąsiadów. Ceną uczciwego i kulturalnego postawienia sprawy jest narażenie się na dyskomfort. „Prawdziwy żal i takie zawstydzenie" świadczą o wysokiej wrażliwości moralnej i emocjonalnej delikatności, bo przecież w obliczu obiektywnej konieczności bojkotu ekonomicznego równie dobrze mogło by się obejść bez tego całego Wersalu w stosunku do pani Meszelowej. Matka pani ze Słonima jest zatem bardziej niż w porządku. Morał jest jasny. Polakowi może być przykro z powodu cierpienia Żydów. Wszelako nie ma on wyjścia. Odnosząc się do złotej myśli Romana Dmowskiego: jest Polakiem, więc ma obowiązki polskie.

Motywy polskiej akcji „Nie kupuj u Żyda!” są w Po-lin oczywiste dla obu stron i nie wymagają żadnego komentarza. Jako „reguła współżycia” są respektowane również przez mniejszość. Polka musi. Żydówka rozumie, okazując psychiczne wsparcie Polce w trudnej sytuacji. Polka odczuwa „prawdziwy żal”. Żydówka płacze. Jak widać, nie tylko większość cierpiała. Dla Jolanty Dylewskiej nie ulega wątpliwości, że dyskryminowana mniejszość rozumiała i szanowała zasady ustanowione przez dominującą większość, zatwierdzając je tym samym jako bezalternatywne. Wypowiedź pani ze Słonima reżyserka zilustrowała archiwalnym obrazem starszej Żydówki, która wychodzi na próg i życzliwie patrzy w obiektyw. Uśmiecha się ciepło. Od jej białej bluzki bije światło. Wywołany z polskiej pamięci „dobry Żyd” bez pretensji przytakuje antysemityzmowi Polaków.

Tyle polskich fantazmatów. W rzeczywistości Żydzi - ofiary niesprawiedliwości i przemocy - wiedzieli, że coraz bardziej jawnie i powszechnie odmawia się im prawa do życia w Polsce. Wiedzieli, że są bezbronni i za wszelką cenę muszą dbać o dobre stosunki z członkami większości, bo w razie eskalacji przemocy może od tego bardzo wiele zależeć 
- z życiem i śmiercią włącznie. Uprawiali więc mimikrę, żeby nie drażnić prześladowców i, o ile to możliwe, jakoś ich do siebie jednak przekonać51.

\section{b) „Jak bida, to do Żyda”52}

Ślady podobnej mimikry i usłużności pojawiają się w innych relacjach. Sekwencja, która kończy się historią ze Słonima, wprowadza temat Żydów w handlu. Jeden z polskich „świadków” opowiada: „Na Polaka to mówiły goj. [...] To co to jest za goj, to jest upośledzenie Polaka!"53. Ton wypowiedzi i zachowanie „świadka” świadczą o jego zaciekłości i satysfakcji: powiedział prawdę o Żydach ludziom, którzy chcą ich wybielać. Jego towarzyszka łagodzi: „Ale się i poszło, i skredytowali, i poczekali, i tego, i poratowali zawsze”.

Następujące później opowieści o żydowskiej życzliwości grają rolę odpowiedzi na zarzut „upośledzenia Polaka”. Agresja, która wyraźnie przebija z pretensji o rzekomo obraźliwe określenie goj, zostaje pominięta. Dylewska traktuje ją jak opis rzeczywistości i chce odpowiedzieć kontrprzykładem. Jest nim taka oto historia, przytoczona przez mężczyznę z Kurowa: „Jak mój ojciec budował stodołę i zabrakło mu blachy na dziesięć metrów kwadratowych na dach, poszedł do spółdzielni «Społem». No to spółdzielnia nie chciała mu bez pieniędzy dać. Poszedł więc do Żyda: «Mośku czy Josku, potrzebne mi dziesięć metrów kwadratowych blachy, a ja nie mam pieniędzy teraz, no to nie pomożecie mi?». «Panie Wójcicki, zawsze panu pomogę. Pan jest gospodarz odpowiedzialny. Znam pana, znamy pana, pan bierze. Jak pan zrobi, kiedy pan będzie miał, to pan odda». O!”.

Jeszcze raz w Po-lin dochodzi do tego samego nieporozumienia. To, co większość traktuje jako dowody przyjaźni i dobrego sąsiedztwa, jest znakiem ukrytej, ale ciągle obecnej przemocy wobec mniejszości. Już sam brak symetrii w kurtuazji może budzić niepokój. Żyd traktuje Polaka z wyraźnym szacunkiem, zwraca się do niego przez „pan”. Polak mówi do Żyda po imieniu. Ponadto, jak wiadomo, handel nie jest domeną sentymentów. Skoro spółdzielnia „Społem” nie chciała udzielić panu Wójcickiemu kredytu, miała widać po temu powody. Możemy sądzić, że w niewielkim Kurowie pracownicy spółdzielni znali klientów równie dobrze, co sympatyczny „Mosiek czy Josek”. Powstaje więc podejrzenie, że z punktu widzenia interesów żydowski kupiec postąpił nierozważnie. Narracja Dylewskiej ukrywa jednak zarówno samą nieracjonalność jego zachowania, jak i jej przyczyny.

Tymczasem przyczyny - przyjacielskich, jak je pamięta Polak - zachowań „Mośka czy Joska" leżą właściwie na wierzchu. Wystarczy to, czego dowiadujemy się z Po-lin o realiach

51 Obrazek z Kałuszyna: „Żydzi twierdzili, iż bez trudu mogliby wybrać burmistrza tej narodowości, ale ojciec wytłumaczył mi później, że i tak by burmistrza wyznania mojżeszowego nadrzędne władze administracyjne nie zaaprobowały. Z opowiadań rodziców dowiedziałem się o (dziś osobliwie wyglądającym) zwyczaju, który panował nie tylko chyba w Kałuszynie. Polegał on na tym, iż świeżo ożeniony policjant przedstawiał swoją żonę wszystkim kupcom żydowskim. Odtąd mogła ona bezpłatnie brać od nich potrzebne jej towary, ale tylko do własnego użytku. Kupcom kalkulowało się to lepiej niż płacenie mandatów za brud w sklepie, a zwłaszcza za nagminnie uprawiany handel w niedzielę (klientów wówczas wpuszczano od tyłu)" [Tazbir 2005: 13]. W powyższym fragmencie zwraca uwagę racjonalizacja i bagatelizacja antysemickiej przemocy. Na temat kategorii i kryteriów brudu zob. Douglas 2007.

52 W całości przysłowie brzmi: „Jak bida, to do Żyda, jak po bidzie, pocałuj mnie w d... Żydzie” [cyt. za: Markiel 2011: 47].

53 Goj - słowo hebrajskie oznaczające członka narodu innego niż żydowski. 
lat trzydziestych, by zrozumieć, że szczodry właściciel sklepu nie chciał narażać się na wrogość, która mogła być dla niego groźna w razie aktów otwartej nienawiści. Lepiej dać Polakowi towar za darmo, niż narażać się na jego zemstę w czasie pogromu. Strategia znana w diasporze od wieków. Przyczyny mogą być również głębsze. W sytuacji bojkotu ekonomicznego i zmniejszania się liczby klientów żydowski sklep musi o nich walczyć. Przejmuje zatem ryzyko, którego nie opłaca się podejmować spółdzielni „Społem”. Żydom pozostawiono najmniej intratną część rynku. Niepewny kredyt jest jedną z ostatnich szans na zarobek. Przemoc większości narzuca mniejszości podporządkowanie niekorzystnym dla niej regułom. Zamiast z przyjaźnią, jak chciałaby Dylewska, mamy tu do czynienia z wymuszeniem spowodowanym przez antysemickie zachowania większości.

W narracji Po-lin rzeczywistość ustępuje miejsca mitowi harmonijnego współżycia. Efekt jest taki, że niemożliwe staje się samo dostrzeżenie dyskryminacji. Dylewska przedstawia przemoc tak, by uchodziła za stosunki dobrosąsiedzkie. Mniejszość musi robić dobrą minę, gdy akurat bierze w skórę - jak pani Meszelowa, właścicielka sklepu ze Słonima. Wobec polskiej opowieści o dobrym sąsiedztwie każda podjęta przez Żydów próba upomnienia się o równe prawa zostałaby uznana za mityczną żydowską niewdzięczność i bezczelność - jednym słowem, agresję. Większość - a z nią bezwiednie twórcy Po-lin - stawiają Żydów przed fałszywą alternatywą: antysemityzm lub „przyjaźń”, tyle że warunkiem tej „przyjaźni” jest zgoda dyskryminowanych na antysemicką przemoc ze strony większości.

\section{c) Żyd-patriota kontra „żydokomuna”}

Wszystko to sprawia, że w muzyce cymbałów, która przez cały film towarzyszy obrazom i dyskretnie przypomina o koncercie Jankiela, pobrzmiewa fałszywa nuta. Większość oczekuje od Żydów polskiego patriotyzmu, ale w świetle narracji Po-lin oczekiwanie to okazuje się równoznaczne z żądaniem podporządkowania większościowym normom. Do porozumienia między Polakami i dobrze wspominanymi Żydami dochodzi w szczególnych, naznaczonych symbolicznie punktach. Na przykład tam, gdzie w grę wchodzi niechęć do komunistów.

„Ten ostatni rok mieszkałam na Berka Joselewicza - wspomina kulturalna pani ze Słonima - u Żydów, państwa Łęcewickich. My tam zajmowaliśmy dwa małe pokoiki, a trzeci przez kuchnię zajmowała matka pana Łęcewickiego. Staruszka była i był między nimi konflikt. Młodzi byli już komunizujący. I ta babcia, ślepa, głuchawa, mówiła do mnie: «Słuchaj, ty zobacz, czy już szabes zachodzi». Czy u rabina świece palą. [...] Więc ja to już za swój święty obowiązek uważałam. Wychodziłam i mówiłam: «Pani Łęcewicka, u rabina już się świeci». «Oj, dziękuję» - szczypała mnie za policzek i szybko zapalała u siebie świece. A ci młodzi już byli... Ona mówiła: «To komuniści! To bolszewicy!»”.

Na rzeczywisty konflikt między starszym, religijnym pokoleniem a młodymi nakłada się stereotyp „żydokomuny”. Komunizm jest dla rozmówczyni Dylewskiej czymś w rodzaju 
żydowskiego przeznaczenia. Stwierdza bowiem, że młodzi byli „już” komunizujący. Ich wybór potwierdza tylko coś, co jest z góry wiadome i nieuniknione. W stereotypie Żydzi są obcymi, którzy przynoszą obcą i wrogą Polakom ideologię. Fantazmat „żydokomuny” służy jednak przede wszystkim do legitymizacji idei nacjonalistycznie rozumianego narodu i reprezentującej go prawicy jako jedynej prawomocnej władzy w polskim państwie ${ }^{54}$. Spotkanie Polaków i zasługujących na życzliwą pamięć Żydów przy okazji niechęci do Żydów-komunistów wydaje się w związku z tym co najmniej podejrzane.

W narracji zdominowanej przez większość „dobry Żyd” zajmuje jedyne akceptowane miejsce: kogoś, kto potwierdza wyobrażenia dominujących - w tym wypadku ich lęki i fobie - na temat grupy, do której sam należy. Akceptując stereotyp „żydokomuny”, przytakuje takiemu podziałowi na swoich i obcych, w którym prawo do decydowania o wspólnych sprawach przypada Polakom i w którym sam znajduje się zawsze na pozycji kogoś, komu nie można w pełni zaufać. Dylewska akceptuje tę postać rzeczy, nie robiąc nic, żeby przywrócić zbiorowej pamięci Żydów-komunistów ani w ogóle Żydów, którzy próbowali wejść na równych prawach w społeczność większościową. W narracji Po-lin zabrakło dla nich miejsca. Zabrakło więc elementu, który zmuszałby do rewizji uprzedzeń i praktyk grupy dominującej.

Zamiast tego rozmówcy Dylewskiej chwalą patriotyzm Żydów. „Uczył mnie historii pan Tau - wspomina ze wzruszeniem mieszkanka Kolbuszowej. - To był Żyd. Wspaniały z niego był historyk i naprawdę nauczył mnie miłości ojczyzny. Bardzo pięknie wykładał nam historię". W świetle tego, co już powiedzieliśmy, żydowska i polska miłość ojczyzny znaczą coś innego. Dla większości patriotyzm polski oznacza akceptację ustanowionego przez nią status quo. W jego zakres wchodzi solidarność ograniczona do etnicznych Polaków-katolików, bojkot żydowskiego handlu, wyobrażenie o „dobrym Żydzie”, który daje kredyt, kiedy odmawia go polski sklep, nienawiść do „żydokomuny” i temu podobne. Wszystko to przyjmowane jest bezrefleksyjnie jako swego rodzaju oczywistość.

Z perspektywy Żydów polski patriotyzm był najczęściej identyfikacją z idealnym obrazem Polski - usilnie wytwarzanym i podtrzymywanym kosztem szczelnego zamykania oczu na rzeczywistość. Mógł być także aktem wiary i nadziei, że wszystko się wreszcie ułoży i będzie można w końcu żyć we własnym kraju jak u siebie. W ekstremalnych przypadkach mógł wreszcie oznaczać zgodę na status quo za cenę uwewnętrznienia perspektywy większościowej, czyli uznania antysemityzmu za racjonalnie uzasadniony, a więc zasłużony. Wymienione objawy owego „zespołu patriotycznego” z największym nasileniem i częstotliwością występowały wśród żydowskiej inteligencji, do której wszak należał pan Tau. Pod każdą postacią polski patriotyzm Żydów polskich zawierał marzenie o równouprawnieniu, a więc o zasadniczej zmianie stosunków. W polskich ustach pochwała Żyda-patrioty nie przewidywała możliwości takiej zmiany. Opowieść o panu Tau brzmi zatem fałszywie. Nie pozwala zobaczyć dyskryminacji i utrwala ją. Na wszelki wypadek nie informuje nas także o dalszych losach polskiego patrioty z Kolbuszowej.

54 Por. wypowiedź Augusta Grabskiego w filmie Anny Zawadzkiej Żydokomuna z 2010 r. 
Żydzi - tak życzliwie wspominani przez rozmówców Dylewskiej - nie wysuwają żadnych żądań. Nie przejawiają cienia protestu, niezadowolenia, oburzenia, goryczy, ironii czy też gniewu lub agresji wobec dominujących. Czują się w polskiej kulturze dobrze. Nie sprawia im ona żadnych poważniejszych problemów. W tej pięknej polskiej opowieści antysemityzm przestaje być praktyką społeczną, która organizuje życie mniejszości jako grupy podporządkowanej i poddanej permanentnej przemocy. Staje się incydentem podobnym do sąsiedzkiej kłótni, która nie zmienia zasadniczo dobrosąsiedzkich stosunków.

Pytanie, czy figura „dobrego Żyda” to zwieńczenie, czy może konstrukcja nośna polskiej opowieści, wymaga oddzielnych badań. Filosemicka struktura nie mogłaby jednak istnieć bez „dobrego Żyda”, którego funkcją jest wystawianie Polakom świadectwa moralności, rozgrzeszanie ich, zaprzeczanie oskarżeniom o antysemityzm i jednoczesne wyrażanie zgody na antysemickie zachowania, potępianie „złych Żydów”, wreszcie legitymizacja większościowej wersji historii.

\section{Cwi Kamionka}

Problematyczną rolę Jolanta Dylewska wyznaczyła Cwi Kamionce - jedynemu polskiemu Żydowi, który wypowiada się w filmie. Cwi Kamionka pojawia się w zakończeniu Po-lin ${ }^{55}$. Mówi zadziwiająco mało. Przyjrzyjmy się, jak reżyserka wprowadza i konstruuje tę filmową figurę. Sekwencja o cmentarzach i śmierci kończy się zdaniem, które podsumowuje i domyka obraz Żydów prezentowany w filmie. Piotr Fronczewski stawia kropkę nad „i”, deklamując: „Na żydowskich cmentarzach w ziemi Po-lin tylko kamienie są świadkami, że leżą tutaj kobiety skromne, pobożne, dzielne i mężczyźni bogobojni, uczeni i prawi”. Jesteśmy w kręgu wyobrażeń większości, gdzie Żydzi to religijni ortodoksi - bezpiecznie zamknięci we własnym świecie, a do tego umarli. Sztetli już nie ma. Koniec opowieści o ziemi Po-lin to Zagłada.

Analizowaliśmy już, w jaki sposób reżyserka przedstawiła Shoah. Echem obrazów opuszczonych cmentarzy są słowa ostatniego z polskich „świadków” o bezpowrotnym przemijaniu wszystkiego. W tle słychać wiatr - ten sam, co w trzech wcześniejszych zapowiedziach Zagłady. W tym momencie pojawia się Cwi Kamionka, który mówi: „W czterdziestym drugim roku, kiedy Niemcy likwidowali getto w Kałuszynie, oni systematycznie wywozili tutaj po sto Żydów, rozstrzeliwali, brali nowych, ci nowi Żydzi kopali wspólne groby, zakopywali zmarłych i tak zabili dwu tysięcy Żydów. Leżą tutaj moi bliscy, osiemdziesiąt osób, razem ze strony ojca i ze strony matki. Imię ojca było Kamionka, a ze strony matki imię było Hepner. [pauza] Tak, te dwie rodziny. Tutaj są zakopani”.

To wszystko. Dylewska nie pyta o nic więcej. Dowiadujemy się tylko o miejscu spoczynku ofiar i o tym, że zbrodni dokonali Niemcy. Cwi Kamionka stoi na wielkim opuszczonym placu. Nieopodal widać domy miasteczka, budynki gospodarcze, szklarnię. Domyślamy

55 Podkreślamy, że chodzi nam tutaj o wykreowaną przez reżyserkę filmową postać pana Kamionki, którą odróżniamy od jego realnej osoby. 
się, że stoi na grobach bliskich, ale w polu widzenia nie ma żadnego śladu po wymordowanych: ani kamienia, ani pomnika, ani tablicy pamiątkowej. Fakt ten przechodzi niezauważony. Reżyserka nie pyta ocalałego, żywego człowieka, co o tym myśli. Nie pyta o jego wspomnienia sprzed wojny ani o to, co przeżył w czasie wojny. Nie pada pytanie, kiedy i dlaczego wyjechał z Polski po wojnie. Narracja filmowa skupia się na czymś innym: sugeruje jedność polskiej i żydowskiej pamięci ${ }^{56}$.

Na ekranie pojawiają się pogodne zdjęcia archiwalne: Kałuszyn 1936. Pozwólmy sobie na dygresję. W tym samym roku, w czerwcu miał miejsce pogrom w sąsiednim Mińsku Mazowieckim ${ }^{57}$. W ciągu kilku najbliższych lat $w$ tych i innych miejscach rozegra się tragedia Żydów - nieustająca w swej schematycznej powtarzalności: „Ci, którzy zamierzali się ratować, doskonale wiedzieli, że nie będzie to łatwe, zdawali sobie sprawę, co ich czeka. Adam Kamienny z Kałuszyna zanotował w swoim dzienniku pisanym w 1944 r.: «będziemy tropieni i ścigani w dzień i w nocy. Nikt nas pod dach nie puści ani kawałka chleba nie poda. Nawet gdyby ktoś chciał, to też nie zrobi tego, z obawy by sąsiad nie zauważył i nie wydał. Musielibyśmy jak dzikie zwierzęta kryć się po lasach, będąc wystawionymi na zamordowanie przez bandytów, od których wszędzie się roiło»" [Engelking 2011: 34]. „W książce Barbary Engelking Jest taki piękny słoneczny dzień... Losy Żydów szukających ratunku na wsi polskiej 1942-1945 mnóstwo jest historii właśnie stąd - Żydów ukrywających się, wydawanych, rozstrzeliwanych na miejscu lub odsyłanych na przystanki żandarmerii czy granatowej policji [...]"[Goźliński 2011: 21] ${ }^{58}$. Koniec dygresji.

Po-lin. Kałuszyn 1936. Słychać porywy wiatru. Widzimy twarze ludzi, którzy pozują przed kamerą, uśmiechają się. Całe wielopokoleniowe rodziny. Jak osiemdziesięcioosobowa rodzina Cwi Kamionki. Ciąg obrazów zostaje przerwany zbliżeniem twarzy pana Kamionki. Cięcie. I zamiast twarzy wysportowanego mężczyzny w krótkiej kurtce, który stoi przed kamerą tu i teraz, widzimy twarz wyposażoną we wszystkie atrybuty ortodoksyjnego wyznawcy judaizmu, utrwaloną na czarno-białej taśmie tam i wtedy. Żywy człowiek z imieniem i nazwiskiem zostaje sprowadzony do wizerunku mitycznego „Żyda” - niejako „zamieniony” i „przetłumaczony” na anonimową ikonę, w której większość zamknęła martwe już ofiary Shoah. Nic to jednak, panowie i panie. Oto czarno-biała dziewczyneczka-„Żydóweczka” macha z ekranu. Do „nas” Polaków, do „nas” chrześcijan, potomków Piasta Kołodzieja i króla Kazimierza Wielkiego. W napisach końcowych nazwisko Cwi Kamionki

56 Pojawienie się sylwetki Cwi Kamionki wprowadzone zostaje panoramą Kałuszyna - inną, ale podobną do obrazu z początku filmu. Wtedy kamera zbliżała się do ziemi, symbolicznie schodziła do grobów, żeby przywołać duchy zmarłych. Wywoływała wspomnienia polskich „świadków”. Zatrzymywała się dokładnie na poziomie, z którego filmował to samo miejsce operator-amator w latach trzydziestych. Błysk światła, jakby film na chwilę się zaciął, i już jesteśmy w tamtym świecie. Zanim pojawi się Cwi Kamionka, kamera także wykonuje travelling w dół, aż do zbliżenia trawy na placu, gdzie zakopano zabitych. Znak zstępowania do grobów zmarłych i budzenia wspomnień żywych jest ten sam. I te same archiwalne materiały ilustrują tak polską, jak żydowską pamięć.

57 „Nieruchomy tłum przygląda się płonącym domom. Nikt nie spieszy z pomocą. Gdzie jest straż? Płoną żydowskie domy i sklepy. To tak zwany pogrom miński. Judka Lejb Chaskielewicz zastrzelił swojego byłego przełożonego Jana Bujaka ze stacjonującego w Mińsku 7. Pułku Ułanów Lubelskich. Powód: jakieś osobiste zaszłości. Ale w miasto poszła legenda, że Bujak zginął, wychodząc z kościoła, a poza tym to zemsta za jego udział w akcji odbijania Żydom handlu (prowadził kantynę dla podoficerów). Cud, że nikt nie zginął, choć pobitych było parę tuzinów; spalonych, zrabowanych, zdemolowanych domów też. Cud - albo ćwiczenia. Bo gdyby 7. Pułk nie był na poligonie, ale w mieście...” [Goźliński 2011: 21]. Pogrom w Mińsku trwał tydzień.

58 W tym samym tekście autor uznaje Po-lin za „dokument doskonały”. 
zostało umieszczone po nazwiskach polskich „świadków”. Oddzielone i jednocześnie poŁączone spójnikiem „oraz”.

W zamknięciu sekwencji z udziałem Cwi Kamionki będziemy oglądać dokładnie tę samą panoramę Kałuszyna, co na początku filmu, tyle że teraz kamera przemieszcza się do góry. Narracja zatacza koło. Początek i koniec układają się w efektowną klamrę. Przywołany we wspomnieniach nieistniejący świat wraca w niebyt. Ostatnie - długie, bo trwające blisko minutę - ujęcie zaczyna się od sylwetki Cwi Kamionki opatrzonej podpisem: „Zvi Kamionka, Izrael. Jeden z niewielu ocalonych Żydów z Kałuszyna”. Forma bierna - „ocalony” - co najmniej zastanawia w odniesieniu do człowieka, który ocalenie zawdzięcza samemu sobie.

Kamera patrzy z wysoka i dokonuje dodatkowego odjazdu w górę. Cwi Kamionka odwraca się i odchodzi. Widzimy go najpierw na wyłożonym „kocimi łbami” placu, potem staje się coraz mniejszy, aż wreszcie znika w ogólnym planie miasteczka. Panorama KaŁuszyna poszerza się. Wśród domów - w centralnym usytuowaniu - rysuje się wieża kościoła, co skądinąd wygląda na kolejny lapsus freudowski. Ekipa filmowa zaczyna czytać imiona pomordowanych. Najpierw każde z osobna, później głosy nakładają się na siebie i zlewają. Obraz ściemnia się aż do czerni. Wzruszenie.

Żywy człowiek, wywodzący się z wnętrza przedwojennego sztetlu, pojawia się w Po-lin. Pamięć ma świetną. Doskonale może o wszystkim opowiedzieć. Sam. Osobiście. Po polsku. Bez tłumacza. Nie zostaje jednak dopuszczony do głosu w przedmiocie, który stanowi temat filmu. Mówi o czym innym: o wojnie i śmierci, choć reżyserka deklarowała, że nie interesuje jej wojna i śmierć, lecz okres przedwojenny i życie. Tego zdumiewającego wyboru nie sposób ani zrozumieć, ani usprawiedliwić. Nawet dobrą wolą twórców filmu.

Trudno oprzeć się wrażeniu, że sposób reżyserowania Cwi Kamionki jest elementem strategicznym - pièce de résistance - opowieści budowanej przez Jolantę Dylewską. Rola, jaką autorka Po-lin przeznaczyła tej postaci, polega na legitymizowaniu konstytutywnych punktów większościowej narracji. Konstrukcja filmowej figury Cwi Kamionki - wraz z miejscem, w którym figura ta się pojawia - umacnia widza w poczuciu, że nie istnieje różnica między pamięcią polską a żydowską. Mimowolnie potwierdza zatem ostatnie słowa komentarza, które zamykają Żydów w tradycyjnej, religijnie rozumianej osobności. Dzieje się tak, mimo iż sam Cwi Hersz Kamionka nie jest chasydem. Cwi Hersz Kamionka jest człowiekiem ze świeckim wyższym wykształceniem, byłym żołnierzem armii Izraela, dokąd wyjechat w 1950 r. ${ }^{59}$

Filmowa figura Cwi Kamionki - za sprawą sposobu, w jaki preparuje ją Jolanta Dylewska - mimowolnie legitymizuje także filmowy opis Zagłady. Dylewska nie pyta swego bohatera o sprawy, których nie sposób pominąć w opowieści o polskiej i żydowskiej pamięci. Stwierdzenie, że Żydów z Kałuszyna zamordowali Niemcy, nie wystarczy. Rozstrzelanie dwóch tysięcy ludzi to trudne zadanie. Potrzeba do tego współpracy wielu osób,

59 Por. e-mail pana Cwi Kamionki do Elżbiety Janickiej z 16 sierpnia 2011 r. 
choćby po to, żeby ofiary nie pouciekały. Co robili wtedy polscy mieszkańcy miasteczka? Wiadomo, że w likwidacji getta w Kałuszynie uczestniczyła miejscowa Ochotnicza Straż Pożarna [Chróścicki 2008: 248] ${ }^{60}$ - instytucja, która w czasie Shoah również gdzie indziej zyskała straszliwą sławę. Czy w Kałuszynie, tak jak w innych polskich miasteczkach, wywózce Żydów towarzyszyły rabunki? Co stało się z mieniem osiemdziesięciu osób z rodzin Hepner i Kamionka? Czy ktoś próbował się ratować? Czy ktoś ocalał? Czy, jak w innych miejscach, również w Kałuszynie wyłapywano uciekinierów? Czy było się gdzie ukryć, a jeśli nie, to dlaczego? Czy donoszono na ukrywających się? Co na to proboszcz miejscowej parafii? Co działo się w Kałuszynie po wojnie? Co Cwi Kamionka myśli i czuje w związku z tym wszystkim?

Skoro żadne z tych pytań nie pada, można przypuszczać, że twórcy filmu, a wraz z nimi dominująca większość, nie są zainteresowani tym, co przeżyli, co czuli i co myśleli ich żydowscy sąsiedzi - ani ci umarli, ani ci, co żyją. Polska pamięć o Zagładzie ma być pamięcią etnicznych Polaków-katolików. Zagłada ma być pamiętana jako - spowodowany zewnętrzną przemocą - koniec żydowskiej obecności w Polsce. Jeśli pamięć Żydów różni się od dominującej wersji wydarzeń, nie ma prawa wejść w obręb większościowej świadomości. Jest czymś zewnętrznym, obcym i w gruncie rzeczy niepotrzebnym.

Cwi Kamionka, nasz współczesny, zostaje w Po-lin przedstawiony jako wysłannik z faktycznej i symbolicznej otchłani, do której polska większość zesłała polskich Żydów. Po odegraniu wyznaczonej mu roli ma tam powrócić. Podpis u dołu ekranu identyfikuje Cwi Kamionkę jako przybysza z daleka. Ot, gość zagraniczny, który przyjechał tylko z wizytą na cmentarz. Filmowa postać odchodzi, pozostawiając winę i odpowiedzialność Niemcom, a Polakom - rolę „świadków” i „strażników pamięci” wraz ze związanym z nią dobrym samopoczuciem. Polska większość nie potrzebuje realnego Cwi Kamionki. Lepiej nawet, żeby czym prędzej zniknął - dyskretnie i bez protestu ${ }^{61}$. Obraz, w którym sylwetka Cwi Kamionki rozpływa się w niebycie, jest tym wygodniejszy, że utwierdza polską większość w proponowanej przez film Po-lin melancholii. A ta okazuje się tym łatwiejsza, że filmowa postać zdaje się nie chcieć niczego od większości: ani zwrotu mienia, ani postawienia złodziei i morderców przed sądem, ani jakiejkolwiek rewizji zbiorowych wyobrażeń.

60 W tym samym numerze czytamy: „Kolejny sprawdzian z lekcji patriotyzmu członkowie OSP zdali w czasie II wojny światowej" [Charczuk 2008: 301].

61 Trudno nie przywołać w tym miejscu fragmentu ze Spowiedzi Calka Perechodnika: „Wszak każdy Polak miał choć jednego przyjaciela Żyda, który go prosił ze łzami w oczach o łaskę ulokowania rzeczy u niego. Wspaniałomyślnie zgadzano się, a jeśli Żyd okazał się grzecznym, to wyjechał do Treblinki i sprawa była wyjaśniona. Majątek się powiększał, sumienie czyste, tout va très bien. Gorzej bywało, jeśli Żyd okazał się natrętnym, chciał żyć nadal i upominał się o swoje rzeczy. Zrozumiała rzecz, że nie warto oddać, wszak Żyd i tak wojny nie przeżyje; ani nie będzie mógł odwdzięczyć się po wojnie, ani też nie będzie mógł skarżyć ich przed sądem i rzucić jakikolwiek cień na ich nieskazitelne imię. Więc powiedzcie sami ludzie, nie warto oddać, po prostu grzech przed Bogiem, my mu oddamy, przyjdą inni i zabiorą" [Perechodnik 2004: 125]. 


\section{Szantaż słodyczą}

Tam, gdzie toczy się otwarty spór, droga do negocjacji pozostaje otwarta. Głosy protestu lub gniewu dają nadzieję na takie wyartykułowanie problemów, w którym strony mają szansę ustalić zasady współżycia na równych prawach. Narracja Po-lin nie przewiduje jednak miejsca na krytykę, tak jak nie przewiduje miejsca na żydowski głos. Co gorsza, harmonia i słodycz obrazu dobrosąsiedzkich stosunków łączących Polaków i Żydów działają jak najskuteczniejszy knebel i szantaż.

Film Dylewskiej odczytano jako dzieło pełne dobrej woli: pieczołowitości wobec archiwalnych materiałów, uwagi okazanej śladom polskich Żydów, życzliwego wsłuchiwania się w głos polskich „świadków”. Życzliwość zobowiązuje. Ci, którym ją okazano, powinni odpowiedzieć tym samym, przyjąć wyciągniętą dłoń. Sytuację znamy z lektury szkolnej pod tytułem Wesele. Jest rok 1900. Polak zwraca się do Żyda per Mosiek ${ }^{62}$, biorąc go na świadka stosunków dobrosąsiedzkich: „No, jesteśmy przyjaciele”. Przyparty do muru Żyd nie chce skłamać, a prawdy powiedzieć nie może. Jego odpowiedź brzmi: „No, tylko że my jesteśmy/ tacy przyjaciele, co się nie lubią" [Wyspiański 1994: 44 - akt I, scena 17] ${ }^{63}$.

Znów zatem mamy do czynienia z podszytym przemocą „zestawem”: przysłowiowa polska wyciągnięta dłoń kontra przysłowiowa żydowska zaciśnięta pięść. Jeśli Żydzi nie uścisną wyciągniętej dłoni, narażą się na zarzut niewdzięczności, a dziś - po Zagładzie - dodatkowo potwierdzą przekonanie, że nie warto było dobrze ich traktować, a co dopiero ratować - słusznie zatem do pomocy, a i obojętności tak bardzo przez Żydów pożądanej, w czasie wojny tłoku nie było. Film Dylewskiej ma pozory przyjaznego gestu, ale nie ma w nim ani propozycji równości, ani miejsca na swobodne wypowiedzenie żydowskiego doświadczenia.

Polski Żyd - realny, który będzie musiał coś zrobić z tym przyjaznym gestem, znajdzie się w nie lada kłopocie. Odmówić nie wypada. A uścisnąć wyciągniętą dłoń? Jeśli przyjmie proponowane warunki, pozostaje mu rola „dobrego Żyda”, który wszystko rozumie, wszystko wybacza i dba o zachowanie status quo. A jeżeli nie? Autorytety, które zawsze wiedzą, gdzie znajduje się złoty środek, będą mówić o braku obiektywizmu, skłonności do przesady i dostrzegania wyłącznie ciemnej strony polsko-żydowskiej historii. Tymczasem - jak głosi maksyma przyświecająca tak zwanemu dialogowi polsko-żydowskiemu - „trzeba szukać tego, co łączy, nie zaś wyolbrzymiać to, co dzieli”. Teraz dopiero „zły Żyd” - niewdzięczny, bezczelny i, co nie daj Boże, mściwy - zasłuży sobie na twardą i zdecydowaną odprawę.

Po-lin. Okruchy pamięci, 2008. Reżyseria: Jolanta Dylewska.

62 Żyd zwraca się w sztuce Wyspiański per pan do wszystkich Polaków, bez względu na ich pozycję społeczną.

63 Bohater dodaje: „No, pan się mną Żydem brzydzi” [Wyspiański 1994: 49]. Sytuacja wyglądałaby zupełnie inaczej, gdyby rozmówcy byli na stopie partnerskiej. Amerykańska pisarka, z rodziny wywodzącej się z Drohobycza, opowiada: „Niedawno podczas pewnego seminarium spotkałam ukraińskiego oficera. Kiedy powiedziałam mu, że moja rodzina pochodzi z Ukrainy, rzucił mi się w objęcia, mówiąc: «Więc jesteśmy rodziną!». Myślałam o tym kilka dni i w końcu wytłumaczyłam mu, dlaczego żaden potomek Żydów, którzy uciekli z Ukrainy przed pogromami, nie powiedziałby, że jesteśmy rodziną" [Waldman 2011: 26]. 
Projekt został sfinansowany ze środków Narodowego Centrum Nauki przyznanych na podstawie decyzji numer DEC-2011/03/B/HS2/05594.

\section{Bibliografia}

Adamczyk-Garbowska Monika, 2009, Macewy ze słów. Księgi pamięci gmin żydowskich, „Kultura Enter”, nr luty; kulturaenter.pl/0/07sn01.html.

Adamczyk-Garbowska Monika, Kopciowski Adam, Trzciński Andrzej (oprac.), 2009, „Księgi pamięci” gmin żydowskich: Tam byt kiedyś mój dom..., Lublin: Wydawnictwo UMCS.

Adorno Theodor W., 1986, Dialektyka negatywna, tłum. Krystyna Krzemieniowa, współpraca Sław Krzemień-Ojak, Warszawa: Wydawnictwo Naukowe PWN.

Adorno Theodor W., 2010, Osobowość autorytarna, tłum. Marcin Pańków, przedmowa do wyd. polskiego Michał Herer, Warszawa: Wydawnictwo Naukowe PWN.

Biedka Ł., 2008, Pomiędzy poczuciem wstydu a poczuciem dumy - psychologiczne zabiegi wokół narodowego wizerunku w debacie historycznej, tekst wygłoszony na IX konferencji Polsko-Izraelskiego Towarzystwa Zdrowia Psychicznego (Israeli-Polish Mental Health Association), Nazaret, 6-8 listopada 2008, maszynopis w archiwum autorów.

Buthak Jan, 1936, Wędrówki fotografa w słowie i obrazie, t. 6: Człowiek twórca krajobrazu - z 16 ilustracjami autora, Wilno: Wydawnictwo „Przegląd Fotograficzny”.

Buthak Jan, b.d. [1939], Polska fotografia ojczysta. Poradnik fotograficzny, Poznań: Księgarnia W. Wilak.

Bułhak Jan, 2003, Kraj lat dziecinnych, oprac. Jolanta B. Kucharska, Gdynia: Gdyńska Oficyna Wydawnicza ASP Rymsza.

Cała Alina (oprac.), 2003, Ostatnie pokolenie. Autobiografie polskiej młodzieży żydowskiej okresu międzywojennego ze zbiorów YIVO Institute for Jewish Research w Nowym Jorku, Warszawa: Sic!

Charczuk Wiesław, 2008, [rec.] Ochotnicze Straże Pożarne południowego Podlasia i wschodniego Mazowsza - dzieje i teraźniejszość, praca zbiorowa pod redakcją R. Dmowskiego, A. Kołodziejczyka i Z. Todorskiego, Warszawa-Siedlce 2007, „Rocznik Kałuszyński”, z. 8, s. 301-306.

Chmielewska Katarzyna, 2004, Sprawozdanie z badania gimnazjalnych podręczników do wychowania obywatelskiego, w: Wyniki monitoringu podręczników gimnazjalnych do języka polskiego, historii, i wiedzy o społeczeństwie (wychowanie obywatelskie i wychowanie do życia w rodzinie) z perspektywy zawartego w nich obrazu mniejszości etnicznych, religijnych i innych, red. Tomasz Żukowski, Warszawa, maszynopis w archiwum autorów.

Chróścicki Władysław, 2008, O ratuszu miasta Kałuszyn, jego budowie i ponad 100-letniej siedzibie Władz Miasta, o budynkach publicznych i urzędnikach, „Rocznik Kałuszyński”, z. 8, s. 243-262.

Douglas Mary, 2007, Czystość i zmaza, tłum. Marta Bucholc, wstęp Joanna Tokarska-Bakir, Warszawa: PIW.

Dylewska Jolanta, 2008a, Historia polsko-żydowska. Rozmowa z Jolanta Dylewska, autorka „Po-lin. Okruchy pamięci” [rozmawiała Agnieszka Dębogórska], „Stopklatka” z 7 listopada 2008; www.stopklatka.pl/wywiady/ wywiad.asp?wi=50237 (dostęp z 1 sierpnia 2012).

Dylewska Jolanta, 2008b, Plunięcie w wieczność. Z Jolantą Dylewską rozmawia Katarzyna Bielas, „Gazeta Wyborcza”/ „Wysokie Obcasy” z 8 listopada 2008; www.wysokieobcasy.pl/wysokie-obcasy/1,96856,5885238 ,Pluniecie_w_wiecznosc.html (dostęp z 22 sierpnia 2012).

Engelking Barbara, 2011, Jest taki piękny słoneczny dzień... Losy Żydów szukających ratunku na wsi polskiej 1942-1945, Warszawa: Stowarzyszenie Centrum Badań nad Zagładą Żydów. 
Glemp Józef, 2010, Jedwabne - wina sprawiedliwie uznana, w: Przeciw antysemityzmowi 1936-2009, oprac. Adam Michnik, t. 3, Kraków: Universitas, s. 570-573.

Goźliński Pawet, 2011, Ostatni seans w Kałuszynie, „Gazeta Wyborcza” z 1 kwietnia 2011; wyborcza. pl/1,75475,9357056,Ostatni_seans_w_Kaluszynie.html (dostęp z 22 sierpnia 2012).

Grabowski Jan, 2011, Judenjagd. Polowanie na Żydów 1942-1945. Studium dziejów jednego powiatu, Warszawa: Stowarzyszenie Centrum Badań nad Zagładą Żydów.

Grabski August (red.), 2007, Żydzi a lewica. Zbiór studiów historycznych, Warszawa: ŻlH.

Hejke Krzysztof, b.d. [1994], Polska romantyczna, wstęp Marek Rostworowski, Warszawa: Editions Spotkania.

Hejke Krzysztof, 2005, [rozmowa], w: W obiektywie. Mistrzowie fotografii polskiej. Rozmowy Hanny Marii Gizy, Warszawa: Rosikon Press.

Hejke Krzysztof, 2009, Polesie, Poznań: Zysk i S-ka.

Hilberg Raul, 2007, Sprawcy, ofiary, świadkowie. Zagłada Żydów 1933-1945, tłum. Jerzy Giebułtowski, Warszawa: Stowarzyszenie Centrum Badań nad Zagładą Żydów \& Cyklady.

Hollender Barbara, 2008, O sąsiadach, którzy nagle zniknęli, „Rzeczpospolita” z 5 listopada 2008, s. A20.

Hurwic Józef, 1996, Wspomnienia i refleksje. Szkic autobiograficzny, Toruń: Wydawnictwo „Comer”.

Janicka Elżbieta, 2008a, Konfrontacja. O audiowizualnej instalacji Zofii Lipeckiej „Po Jedwabnem” (2001-2003), w: Zofia Lipecka, Po Jedwabnem, red. Hanna Wróblewska, Warszawa: Zachęta Narodowa Galeria Sztuki, s. 24-44.

Janicka Elżbieta, 2008b, Mord rytualny z aryjskiego paragrafu. O książce Jana Tomasza Grossa „Strach. Antysemityzm w Polsce tuż po wojnie. Historia moralnej zapaści”, „Kultura i Społeczeństwo”, nr 2, s. 229-252.

Janicka Elżbieta, 2010, Pamięć nieprzyswojona?, „Kultura Współczesna”, nr 1, s. 190-201.

Janion Maria, 2000, Spór o antysemityzm. Sprzeczności, wątpliwości i pytania, w: taż, Do Europy - tak, ale razem z naszymi umartymi, Warszawa: Sic!.

Jurkowlaniec Zofia (red.), 2007, Jan Buthak (1876-1950). Fotografik / Pictorial Photographer, tłum. na język ang. Aleksandra Rodzińska-Chojnowska, Warszawa: Muzeum Narodowe, Warszawa 2007.

Karski Jan, 1999, Widziałem, oprac. Michał Cichy, „Gazeta Wyborcza” z 2-3 października 1999, s. 14.

Kletowski Piotr, Do ciebie, człowieku!, „Tygodnik Powszechny” z 15 czerwca 2008; tygodnik.onet. pl/33,0,10996,1,artykul.html (dostęp z 22 sierpnia 2012).

Libionka Dariusz, 2006, ZWZ-AK i Delegatura Rządu RP wobec eksterminacji Żydów polskich, w: Polacy i Żydzi pod okupacją niemiecka 1939-1945. Studia i materiały, red. Andrzej Żbikowski, Warszawa: IPN, s. 15-139.

Markiel Tadeusz, 2011, Gniewczyna w czas wojny, w: Tadeusz Markiel, Alina Skibińska, „Jakie to ma znacze nie, czy zrobili to z chciwości?" Zagłada domu Trynczerów, Warszawa: Stowarzyszenie Centrum Badań nad Zagładą Żydów.

Miłosz Czesław, 1999, Wyprawa w dwudziestolecie, Kraków: Wydawnictwo Literackie.

Ostrowska Joanna, 2009, Polsko-żydowskie okruchy pamięci. „Po-lin” Jolanty Dylewskiej jako świadectwo zapomnianego świata, „Res Publica Nowa” 2009, nr 5, s. 68-72.

Perechodnik Calek, 2004, Spowiedź. Dzieje rodziny żydowskiej podczas okupacji hitlerowskiej w Polsce, oprac. David Engel, Warszawa: Ośrodek „Karta”.

Poliakov Léon (red.), 2010, Historia antysemityzmu, t. 3: 1945-1993, tłum. Agnieszka Rasińska-Bóbr, Oskar Hedemann, Kraków: Universitas.

Sekula Allan, 2010, Społeczne użycia fotografii, tłum. Krzysztof Pijarski, Warszawa: Zachęta \& Wydawnictwa Uniwersytetu Warszawskiego.

Sobolewski Tadeusz, 2008, Film z tamtego świata, „Gazeta Wyborcza” z 8 listopada 2008; wyborcza. pl/1,75475,5896960,Film_z_tamtego_swiata.html. 
Sobolewski Tadeusz, 2009/2010, Polskie kino dojrzewa, „Gazeta Wyborcza” z 31 grudnia 2009 - 1 stycznia 2010; wyborcza.pl/1,75475,7410028,Polskie_kino_dojrzewa.html.

Szymanowicz Maciej, 2009, W służbie idei. Uwagi o fotografii ojczystej, w: Sztuki wizualne jako nośniki ideologii, red. Marcin Lisiecki, Toruń: Wydawnictwo Adam Marszałek, s. 58-86.

Śmiałowski Piotr, 2008, Po-lin. Okruchy pamięci, „Kino”, nr 10, s. 91.

Tazbir Janusz, 2005, O Kałuszynie i - sitarzach, „Rocznik Kałuszyński”, nr 5.

Tokarska-Bakir Joanna, 2004, Żydzi u Kolberga, w: taż, Rzeczy mgliste. Eseje i studia, Sejny: Pogranicze, s. $49-72$.

Tokarska-Bakir Joanna, 2011, Następstwa Holocaustu w relacjach żydowskich i w pamięci polskiej prowincji w świetle badań etnograficznych, w: Następstwa zagłady Żydów. Polska 1944-2010, red. Feliks Tych i Monika Adamczyk-Garbowska, Lublin: Wydawnictwo UMCS \& ŻIH.

Tych Feliks, 1999, Długi cień Zagłady. Szkice historyczne, Warszawa: ŻıH.

Waldman Ayelet, 2011, Zagonimy was batem do domu. Z Ayelet Waldman rozmawia Magdalena Lankosz, „Gazeta Wyborcza”/,Wysokie Obcasy” z 27 sierpnia 2011; www.wysokieobcasy.pl/wysokieobcasy/1,53662,10173372,Zagonimy_was_batem_do_domu.html (dostęp z 22 sierpnia 2012).

White Hayden, 2010, Poetyka pisarstwa historycznego, red. Ewa Domańska, Marek Wilczyński, wyd. 2, Kraków: Universitas.

Wilczyk Wojciech, 2009, Niewinne oko nie istnieje, tłum. Soren Gauger, Łódź - Kraków: Atlas Sztuki - Korporacja Ha!art.

Wróblewski Janusz, 2008, Po-lin. Okruchy pamięci. Świadectwa koegzystencji Żydów i Polaków na Kresach Wschodnich, „Polityka” z 10 listopada 2008; www.polityka.pl/kultura/film/273316,1,recenzja-filmu-polin-rez-jolanta-dylewska.read.

Wyspiański Stanisław, 1994, Wesele, oprac. Jan Nowakowski, Wrocław-Warszawa-Kraków: Zakład Narodowy im. Ossolińskich [Biblioteka Narodowa, seria 1, nr 218].

Zawadzka Anna, 2009, Żydokomuna. Szkic do socjologicznej analizy źródeł historycznych, „Societas / Communitas", nr 2, s. 199-243.

Żbikowski Andrzej, 2004, Posłowie, w: Samuel Willenberg, Bunt w Treblince, Warszawa: Biblioteka „Więzi”.

Żukowski Tomasz, 2001a, Mówić, nie mówiąc za wiele. O dyskusji w sprawie Jedwabnego, „Bez Dogmatu”, nr 47.

Żukowski Tomasz, 2001b, Panu Bogu świeczkę i diabłu ogarek, „Midrasz”, nr 6 (50) czerwiec; www.midrasz. pl/archiwum.php\#article-content.

Żukowski Tomasz, 2005, Ballady o Szoa, w: Stosowność i forma. Jak opowiadać o Zagładzie, red. Michał Głowiński, Katarzyna Chmielewska i in., Kraków: Universitas.

Żukowski Tomasz, 2010, Savoir-vivre. Ironiczne strategie w „Spowiedzi” Calka Perechodnika, „Teksty Drugie”, nr 6, s. 38-55 